\title{
A Comparative Analysis of the Environmental Policies in China and Pakistan: Developing a Legal Regime for Sustainable China-Pakistan Economic Corridor (CPEC) under the Belt and Road Initiative (BRI)
}

\author{
M Jahanzeb Butt*, Yen Chiang Chang** \\ \& Khadija Zulfiqar***
}

\begin{abstract}
Recent studies reflect that the legal regime of the China-Pakistan Economic Corridor (CPEC) is one of the crucial gateways of the Belt and Road Initiative (BRI). It is somehow replete with multiple environmental perplexities. Environmental quandary is expected in the BRI's development projects. This turns it into a main reason behind a recent shift in China's environmental policies owing to international commitments. The broader prospects involved offer a larger role in the international organisations. In accordance with the global environmental policy transformation, China integrates climate change as a new science with terrestrial and marine ecosystems. In the development of CPEC projects, there are lessons to be learnt by Pakistan also. It needs to integrate its environmental policies to refine its international status and maintain itself as a sustainable and principal partner of China's BRI. This study explores the inadequacies in
\end{abstract}

\footnotetext{
* M. Jahanzeb Butt is a PhD Scholar, School of Law, Dalian Maritime University, China.

** Yen Chiang Chang is Professor of International Law, School of Law, Dalian Maritime University, China.

***Khadija Zulfiqar is a PhD Scholar, School of Law, Dalian Maritime University, China.
}

\footnotetext{
@ 2021 by the Islamabad Policy Research Institute.

IPRI Journal $\square \mathrm{XXI}$ (1): 83-122

https://doi.org/10.31945/iprij.210104
} 
M Jahanzeb Butt, Yen Chiang Chang \& Khadija Zulfiqar

Pakistan's existing environmental policy while comparing it with the Chinese counterpart, and Chinese environmental policy shift, which is being implemented on CPEC and BRI projects.

Keywords: Sustainable Development, Environmental Policy, Belt and Road Initiative (BRI), China Pakistan Economic Corridor (CPEC), Environmental Law. 
A Comparative Analysis of the Environmental Policies in China and...

\section{Introduction}

7 ight to life,' redefined by the Supreme Court of Pakistan in Shehla Zia Vs Water and Power Development Authority, ${ }^{1}$ evolved the 1 historical perspective of human existence in Pakistan's Constitution. According to the judgement, the term 'life is unconfined to vegetative or animal life and covers all human existence facets. The law protects any person from being exposed to hazards of electromagnetic fields or any other such hazards that may be due to installation and construction. ${ }^{2}$ This concept entrenched the citizens' environmental-health rights on a new 'ecological foundation's' benchmark in constitutional interpretation and development. ${ }^{3}$ The Supreme Court recommended restructuring the environmental impact assessment (EIA) procedures, ensuring environmental quality for citizens' healthy lives.

The Supreme Court endorsed that a new environmental protection policy under international commitments was necessary to maintain Pakistan's international image. Given that judicial verdict and such other imperatives, Pakistan's environmental policies were restructured under the Declaration of the United Nations Conference on the Human Environment (Stockholm Declaration) ${ }^{4}$ and the Declaration of the United Nations Conference on Environment and Development (RIO Declaration). ${ }^{5}$ Altogether, the Stockholm and Rio Declarations stipulate sustainable

\footnotetext{
${ }^{1}$ Shehla Zia v. W.A.P.D.A, 1994 All Pakistan Law Decisions 693 (n.d.).

${ }^{2}$ Shehla Zia v. W.A.P.D.A, 1994 All Pakistan Law Decisions., See also: Article 9 "Constitution of the Islamic Republic of Pakistan, 1973: As Amended up-to-Date. Lahore: All Pakistan Legal Decision, 2015” (n.d.).

${ }^{3}$ Jawad Hassan, Environmental Laws of Pakistan: With the Exhaustive Commentary on the Pakistan Environmental Protection Act, 1997, Containing All Rules, Regulations, Latest Case Law and Treaties (Book Biz, 2006).

4 "Declaration of the United Nations Conference on the Human Environment," U.N. Doc. A/Conf.48/14/Rev. 1 § (1973). See also: Pakistan Environmental Protection Agency, Archives, "Brief on Pakistan Environmental Protection Act, 1997," Brief (Islamabad, Pakistan: Ministry of Climate Change, Pakistan, May 12, 2012), http://www.environment.gov.pk/images/webcontent/brf-act1997.pdf.

5 "United Nations Conference on Environment and Development/Rio Declaration on Environment and Development," UN Doc. A/CONF.151/26 (vol. I) § (1992). See also: United Nations Department on Social and Economic Affairs, "Rio Declaration on Environment and Development: Application and Implementation," Report of the Secretary General, Commission on Sustainable Development (Fifth Session) (Geneva, Switzerland: United Nations Economic and Social Council, October 12, 1999), https://www.un.org/esa/documents/ecosoc/cn17/1997/ecn171997-8.htm.
} 


\section{Jahanzeb Butt, Yen Chiang Chang \& Khadija Zulfiqar}

development mechanisms to be adopted by any ratifying country to balance development projects and environmental protection. The Lahore High Court interpreted sustainable development in the Maple Leaf Cement Factory Vs Environmental Protection Agency ${ }^{6}$ by redefining sustainable development through four legal principles: intergenerational equity (the need to preserve natural resources for the benefit of future generations), sustainable exploitation or usage (purported to exploit natural resources prudently, rationally, wisely, or appropriately), equitability (implying that the use by one state must take account of the needs of other states), and scientific knowledge integration (ensuring that environmental considerations were integrated into economic and other development plans, programmes and projects, and that development needs were taken into account in applying the environmental objectives). ${ }^{7}$

Environmental protection is a predicament for Pakistan already facing water shortages, sewerage problems, intermittent floods and frequent droughts. ${ }^{8}$ Accordingly, recent literature depicts that sustainable development is still a quagmire in the environmental policy mechanisms despite Pakistan's international commitments and judicial obligations. ${ }^{9}$ Among them, the most pertinent study conducted by the International Union for Conservation of Nature on the 'Environmental Toll of China Pakistan Economic Corridor (CPEC)' under the Belt and Road Initiative (BRI), illustrates that the risk to the environment has certainly increased. ${ }^{10}$

${ }^{6}$ Maple Leaf Cement Factory Vs Environmental Protection Agency, 2018 All Pakistan Law Decisions 255 (n.d.).

${ }^{7}$ Maple Leaf Cement Factory Vs Environmental Protection Agency, 2018 All Pakistan Law Decisions.

${ }^{8}$ Amad-ud-din Fazil, "Environment and Water Issues in Pakistan," Lahore High Court Research Center (Lahore, Pakistan: Lahore High Court Research Center, February 13 2014), https://doi.org/10.2139/ssrn.2395669.

9 Aamir Saeed, "As Climate Impacts Hit, Pakistan Faces Migration Surge: Experts," Reuters, November 27, 2015, sec. World News, https://www.reuters.com/article/uspakistan-climatechange-migration-idUSKBNOTG02J20151127.

${ }^{10}$ Noor U1 Hadi, Saima Batool and Assad Mustafa, "CPEC: An Opportunity for a Prosperous Pakistan or Merely a Mirage of Growth and Development.," Dialogue (Pakistan) 13, no. 3 (2018): 295-311. See also, Gland, "Mainstreaming Environment in the China-Pakistan Economic Corridor Is Must to Protect Fragile Environment of Pakistan," International Union for Conservation of Nature (blog), December 14, 2016, https://www.iucn.org/news/pakistan/201612/mainstreaming-environment-chinapakistan-economic-corridor-must-protect-fragile-environment-pakistan. And Siegfried O. Wolf, "Chapter - 6 - Assessment," in The China-Pakistan Economic Corridor of the 
A Comparative Analysis of the Environmental Policies in China and...

It observes that CPEC, while being most significant development project in Pakistan's history via the most extensive interconnectivity pattern of $\mathrm{BRI}$, is rather prematurely supervised under the Bilateral Investment Treaty (BIT) and Free Trade Agreements (FTA) between Pakistan and China. ${ }^{11}$ There are no environmental protection provisions in any of the treaty or agreement, nor are there stringent mechanisms to assess environmental degradation or harm. While referring to the Global Climate Risk Index (2014 - 2020), it opined that Pakistan would be one of the worst affected states by climate change. ${ }^{12}$ It criticised Pakistan's environmental policies, arguing that environment as a broad phenomenon remains underdeveloped in national and provincial environmental frameworks. ${ }^{13}$ Furthermore, it stated that mere tree-plantation campaigns at the national level under the federal and provincial government departments will not fulfil the ever-growing ecological problems and may aggravate underground water problems. ${ }^{14}$

Like the other BRI states, Pakistan requires major infrastructure, trade and energy projects like the CPEC to meet the needs of its population and growing societal exigencies. Parellel to this, China's BRI is in sync with its environmental policy implications, balancing it with development predicated on sustainability. Shift in the Chinese environmental regime is, however, inviolable and no less crucial in building its trust in international organisations. ${ }^{15}$ Implementing BRI through greater transparency and accountability in each perspective, accompanied by environmental protection regimes, is fundamental to

Belt and Road Initiative: Concept, Context and Assessment, 1st ed. (Brussels, Belgium: Springer, 2019), 125-241 at 239.

${ }^{11}$ Muhammad Naeem Akbar Qazi, "China Pakistan Economic Corridor: A Game Changer Project," Review of Economics and Development Studies 5, no. 3 (2019): 541-50, http://reads.spcrd.org/index.php/reads/article/view/142.

${ }^{12}$ Monitoring Desk, "Pakistan Ranks Fifth on Global Climate Risk Index," Dawn, December 5, 2019, sec. Pakistan., see also, David Eckstein et al., "Global Climate Risk Index 2020,” Briefing Paper (Germany: German Watch), accessed March 6, 2020, http://germanwatch.org/en/17307.

${ }^{13}$ Zile Huma, "Pakistan’s Environmental Challenges," Daily Times, June 2018, sec. Perspectives.

${ }^{14}$ News Desk, "PM Imran Launches Pakistan's Largest Tree Plantation Drive," The Express Tribune, August 9, 2020, sec. Pakistan.

${ }^{15}$ Kun-min Zhang and Zong-guo Wen, "Review and Challenges of Policies of Environmental Protection and Sustainable Development in China," Journal of Environmental Management 88, no. 4 (September 1, 2008): 1249-61, https://doi.org/10.1016/j.jenvman.2007.06.019. 


\section{Jahanzeb Butt, Yen Chiang Chang \& Khadija Zulfiqar}

China's gaining international legitimacy. ${ }^{16}$ Therefore, China's updated environmental policies present significant methods of integration, sustainability, systemisation, capacity building, defragmentation, clarity, consciousness and equitability. ${ }^{17}$

Based on the above, this study aims to conduct a comparative analysis of the existing environmental policy framework of Pakistan and China. Although, literature on the environmental issues related to CPEC is limited to the perspectives of management and finance, it offers substantial environmental protection methods and sustainable development with the observatory scientific methods. ${ }^{18}$ Conversely, literature on Pakistan's environmental law and policy is with the judicial interpretation or limited to jurisprudential and dogmatic methods. ${ }^{19}$ The real-time or systematic environmental law, policy and governance complications are not indemnified throughout the literature to evaluate the infrastructure or development projects identical to CPEC. ${ }^{20}$

\footnotetext{
${ }^{16}$ Nguyen Thi Lan Anh and Mai Ngan Ha, "Legal Challenges to the Belt and Road Initiative," in Critical Reflections on China's Belt \& Road Initiative, ed. Alan Chong and Quang Minh Pham (Singapore: Springer, 2020), 159-74, https://doi.org/10.1007/978981-13-2098-9_9.

${ }^{17}$ Fernando Ascensão et al., "Environmental Challenges for the Belt and Road Initiative," Nature Sustainability 1, no. 5 (May 2018): 206-9, https://doi.org/10.1038/s41893-0180059-3.

${ }^{18}$ See for example, Qazi, "China Pakistan Economic Corridor."

${ }^{19}$ See for example: Jawad Hassan, "Environmental Law of Pakistan," Global Environmental Law Annual 1996 (1996): 15, https://heinonline.org/HOL/Page?handle=hein.journals/gloenvla4\&id=17\&div=\&collecti on=; Martin Lau, "The Role of Environmental Tribunals in Pakistan: Challenges and Prospects," Yearbook of Islamic and Middle Eastern Law Online 1, no. aop (December 27, 2019): 1-48, https://doi.org/10.1163/22112987_02001001.

${ }^{20}$ See for Example: Mahmood A. Khawaja, Sumble Saeed, and Maham Urooj, "Preliminary Environmental Impact Assessment, Study of China-Pakistan Economic Corridor, Northern Route Road Construction Activities in Khyber Pakhtunkhwa, Pakistan" (Islamabad, Pakistan: Sustainable Development Policy Institute, January 2018), https://www.sdpi.org/publications/files/Preliminary-Environmental-ImpactAssessment-Study-of-CPEC-NRRC-Activities-in-KPK-Pakistan(PB-59).pdf; Irfan Zafar et al., "A Decision Support Framework for Sustainable Highway Alignment Embracing Variant Preferences of Stakeholders: Case of China Pakistan Economic Corridor," Journal of Environmental Planning and Management 63, no. 9 (July 28, 2020): 155084, https://doi.org/10.1080/09640568.2019.1672524; Ruilian Zhang, Francis Andam, and Guoqing Shi, "Environmental and Social Risk Evaluation of Overseas Investment under the China-Pakistan Economic Corridor," Environmental Monitoring and Assessment 189, no. 6 (2017): 253, https://doi.org/10.1007/s10661-017-5967-6.
} 


\section{A Comparative Analysis of the Environmental Policies in China and...}

This study, therefore, is an analysis of environmental law, policy and governance of Pakistan, poised towards the CPEC projects under BRI, including power generation, infrastructure (road networks and railways), Gwadar port, and city. China's environmental governance framework is critical enough to analyse the existing academic criticism on CPEC while inculcating an impact-based research. Towards the end of this study, the summation suggests effective methods for Pakistan to integrate environmental protection with the economic development, ensuring sustainable development.

\section{Environmental Policy of China}

\subsection{Historical Perspective}

Before enacting the Environmental Protection Law of 2015 (EPL), China's environmental policies received sheer criticism in academic literature. ${ }^{21}$ Much needed economic development devastated China's environment, climate and water due to ineffective enforcement. Although China's environmental regulations followed the Stockholm Declaration and significant incorporation of rules related to the Rio Declaration in its environmental policies, the framework remained fragmented, and regulations were often violable. ${ }^{22}$ The new law, known as EPL, while establishing 'polluter pay principle' incorporated in the environmental policy, has proven significant in the environmental recovery. ${ }^{23}$ Concurrently, EPL has enabled the centralised administrative and political governance in holistic implementation. ${ }^{24}$ The central government issues strict regulations, and the provincial and local authorities carry out effective monitoring and enforcement. Under the State Council, a Commission for the Protection of Environmental and Natural Resources (CPENR) establishes environmental policies and guidelines. ${ }^{25}$ The State

\footnotetext{
${ }^{21}$ Yan Wang, Richard K Morgan and Mat Cashmore, "Environmental Impact Assessment of Projects in the People's Republic of China: New Law, Old Problems," Environmental Impact Assessment Review 23, no. 5 (August 1, 2003): 543-79, https://doi.org/10.1016/S0195-9255(03)00071-4.

${ }^{22}$ Bo Zhang et al., "A New Environmental Protection Law, Many Old Problems? Challenges to Environmental Governance in China," Journal of Environmental Law 28, no. 2 (July 1, 2016): 325-35, https://doi.org/10.1093/jel/eqw014.

${ }^{23}$ Stefanie Beyer, "Environmental Law and Policy in the People's Republic of China," Chinese Journal of International Law 5, no. 1 (January 1, 2006): 185-211, https://doi.org/10.1093/chinesejil/jmk002.

${ }^{24}$ Beyer.

${ }^{25}$ Zhang and Wen, "Review and Challenges of Policies of Environmental Protection and Sustainable Development in China."
} 


\section{Jahanzeb Butt, Yen Chiang Chang \& Khadija Zulfiqar}

Environment Protection Administration (SEPA) is responsible for implementing regulations related to the protection of water, air and soil ecosystems, including waste disposal. ${ }^{26}$ Authorities like the State Oceanic Administration (SOA), Council of Agriculture (COA), National Development and Reform Commission (NDRC), Ports and Transport Administration (PTA) work closely with SEPA in implementing environmental-related policies. ${ }^{27}$

\section{Figure 1: Integrated Environmental Protection Governance Mechanism of China}

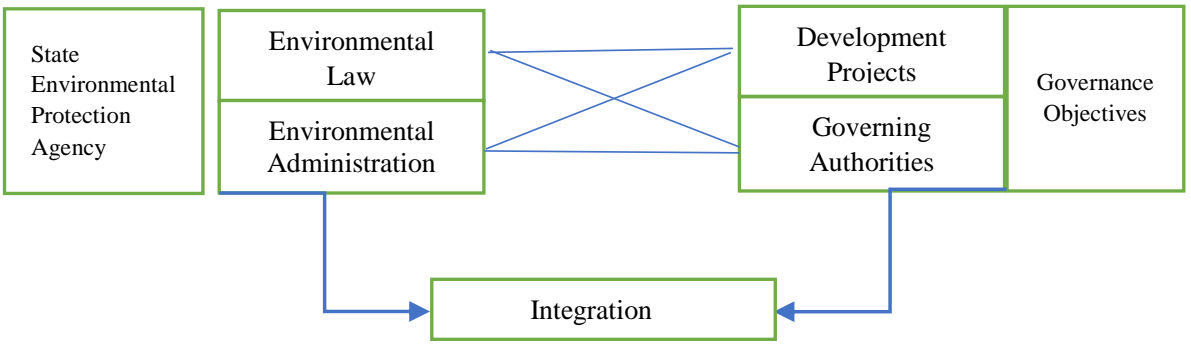

Source: Prepared by Authors, data retrieved from the research articles of 'Kui Liu and Boqiang Lin, Dawn Winalski and Mark Wang. ${ }^{28}$

${ }^{26}$ Abigail R. Jahiel, "The Organization of Environmental Protection in China," The China Quarterly, no. 156 (1998): 757-87.

${ }^{27}$ Elizabeth C. Economy, "The Great Leap Backward - The Costs of China's Environmental Crisis," Foreign Affairs 86 (2007): 38; Qiang Wang and Yong Chen, "Energy Saving and Emission Reduction Revolutionizing China's Environmental Protection," Renewable and Sustainable Energy Reviews 14, no. 1 (January 1, 2010): 535-39, https://doi.org/10.1016/j.rser.2009.08.006.

${ }^{28}$ Kui Liu and Boqiang Lin, "Research on Influencing Factors of Environmental Pollution in China: A Spatial Econometric Analysis," Journal of Cleaner Production 206 (January 1, 2019): 356-64, https://doi.org/10.1016/j.jclepro.2018.09.194; Dawn Winalski,

"Cleaner Water in China - The Implications of the Amendments to China's Law on the Prevention and Control of Water Pollution," Journal of Environmental Law and Litigation 24 (2009): 181; Mark Wang et al., "Rural Industries and Water Pollution in China," Journal of Environmental Management 86, no. 4 (March 1, 2008): 648-59, https://doi.org/10.1016/j.jenvman.2006.12.019. 


\section{A Comparative Analysis of the Environmental Policies in China and...}

The spectrum of China's environmental governance model as explained in Figure -1 is a classic example of sustainable development since the governing authorities strictly follow environmental compliance while implementing development projects. The balance between environmental protection and economic development is managed under the following regulations by undertaking precautionary and preventive measures. The environmental and the governing authorities work together for predictability and mitigation of the environmental harms. Moreover, there is a proper mechanism for waste, water and sanitation management, forest (tree) or green area protection in a manner that ecological concerns do not impede economic development.

\subsection{The Law on the Prevention and Control of Environmental Pollution (LPCEP)}

The LPCEP of 1995 aims to reduce solid waste generated through domestic household rubbish, debris from the construction projects and trash from the markets. ${ }^{29}$ The local and provincial authorities independently manage solid waste by conducting inspections of facilities provided by the private market to their consumers or residents. ${ }^{30}$ The local and provincial authorities report to central authorities, such as SEPA, for the official record. SEPA is further empowered to inspect the solid waste dumping and recycling areas in the provinces and cities. ${ }^{31}$

\subsection{The Law on the Prevention and Control of Water Pollution (LPCWP)}

LPCWP, initially enacted in 1984, was amended twice in 1996 and 2008, following the Convention on Biological Diversity (Biodiversity Convention) and Rio Declaration. ${ }^{32}$ This law regulates the industrial,

\footnotetext{
${ }^{29}$ Revisions to China's law on the Prevention and Control of Environmental Pollution by Solid Wastes (2020 Amendment) came into effect on September 1, 2020 (no 162/20), See also: Zhilin $\mathrm{Mu}$, Shuchun Bu, and Bing Xue, "Environmental Legislation in China: Achievements, Challenges and Trends," Sustainability 6, no. 12 (December 2014): 8967-79, https://doi.org/10.3390/su6128967.

${ }^{30}$ Gengyuan Liu et al., "Prevention and Control Policy Analysis for Energy-Related Regional Pollution Management in China," Applied Energy 166 (March 15, 2016): 292 300, https://doi.org/10.1016/j.apenergy.2015.06.032.

${ }^{31}$ Kui Liu and Boqiang Lin, "Research on Influencing Factors of Environmental Pollution in China: A Spatial Econometric Analysis," Journal of Cleaner Production 206 (January 1, 2019): 356-64, https://doi.org/10.1016/j.jclepro.2018.09.194.

32 Law of the People's Republic of China on Prevention and Control of Water Pollution, 1996 (Amended 1996, into force, 1984) (no 182/34), See also, Dawn Winalski, "Cleaner
} 


\section{Jahanzeb Butt, Yen Chiang Chang \& Khadija Zulfiqar}

urban, agricultural and rural, and vessel pollution discharging in rivers, streams and sewerage lines by licensing the entities to perform centralised disposal of effluents. ${ }^{33}$ In this law of 2018, the latest Amendment acknowledges the Convention on the Protection and Use of Transboundary Watercourses and International Lakes precisely focuses the agricultural wastewater and drinking water safety. ${ }^{34}$

\subsection{The Law on the Prevention and Control of Atmospheric Pollution (LPCAP)}

The most pertinent shift in China's environmental regime after the United Nations Framework ratified Climate Change Convention (UNFCCC) is the National Action Plan on the Climate Change $(2014-2020) .{ }^{35}$ China's commitment through the LPCAP of 2014, is the primary legislation governing emissions. The Department of Climate Change is an autonomous authority under the State Council, and while accompanying, the authorities governing the industrial or high emission producers establishes targets and guidelines. It actualises Intended National Determined Contribution (INDC) and Integrated Emissions Standards for Air Pollutants to reduce emissions at the provincial and local levels. ${ }^{36}$ In addition, the city governments in China promote and subsidise light-duty vehicles and renewable energy vehicles.

\footnotetext{
Water in China - The Implications of the Amendments to China's Law on the Prevention and Control of Water Pollution," Journal of Environmental Law and Litigation 24 (2009): 181.

${ }^{33}$ Mark Wang et al., "Rural Industries and Water Pollution in China," Journal of Environmental Management 86, no. 4 (March 1, 2008): 648-59, https://doi.org/10.1016/j.jenvman.2006.12.019.

${ }^{34}$ Huiping Chen, Alistair Rieu-Clarke and Patricia Wouters, "Exploring China's Transboundary Water Treaty Practice through the Prism of the UN Watercourses Convention," Water International 38, no. 2 (March 1, 2013): 217-30, https://doi.org/10.1080/02508060.2013.782134.

${ }^{35}$ Mehran Idris Khan and Yen-Chiang Chang, "Environmental Challenges and Current Practices in China-A Thorough Analysis," Sustainability 10, no. 7 (July 2018): 2547, https://doi.org/10.3390/su10072547.

36 "Energy Consumption and Carbon Emissions in a Coastal City in China," Procedia Environmental Sciences 4 (January 1, 2011): 1-9, https://doi.org/10.1016/j.proenv.2011.03.001.
} 
A Comparative Analysis of the Environmental Policies in China and...

\subsection{The Law on Marine Environmental Protection (LMEP)}

LMEP of 1982 was amended in 1999, establishing the State Oceanic Administration (SOA) under the Ministry of Natural Resources. ${ }^{37}$ The State Oceanic Administration is fully responsible for protecting the marine environment and collaborates with the Fishery Administration under the Ministry of Agriculture in a holistic manner. ${ }^{38}$ LMEP is an integrated version of the maritime environmental law as per the international commitments, such as the United Nations Convention on Law of the Sea (UNCLOS), Convention on the Prevention of the Marine Pollution by Dumping of Wastes and Other Matter (London Convention), and Protocol Relating to the Prevention of Marine Pollution by the Dumping of Waste and Other Matter, and Convention of the Antarctic Marine Living Resources. ${ }^{39}$

\subsection{EIA Regulations}

The EIA Regulations were introduced in the 1970s, to address the possible environmental considerations for the development projects. ${ }^{40}$ Initially, due to weak systemic and professional capacity, the scientific concerns remained unaddressed. ${ }^{41}$ The authority's capability was feeble to take precautionary and preventive measures, predictability, and mitigation. Over time the authorities equipped themselves with quality environmental governance tools, including predictability, precaution, prevention, equitability, inclusiveness, and rationality. There are detailed policy patterns in protecting the environment with the institutional capacity

\footnotetext{
37 Yen-Chiang Chang, "A Note on a Comparison of the Ocean Governance System Between Mainland China and Taiwan," Ocean Development \& International Law 43 , no. 4 (2012): 311-29.

${ }^{38}$ Yen-Chiang Chang, Nannan Wang and Yue Zhao, "The Current Development of the Ocean Governance Mechanism in China," Coastal Management 41, no. 2 (March 1, 2013): 120-33, https://doi.org/10.1080/08920753.2013.768515.

${ }^{39}$ Sulan Chen and Juha I. Uitto, "Governing Marine and Coastal Environment in China: Building Local Government Capacity Through International Cooperation," China Environment Series, no. 6 (January 2003): 67-80,

http://citeseerx.ist.psu.edu/viewdoc/download?doi=10.1.1.519.2635\&rep=rep1\&type=pd f.

${ }^{40}$ Cun-kuan Bao, Yong-sen Lu and Jin-Cheng Shang, "Framework and Operational Procedure for Implementing Strategic Environmental Assessment in China," Environmental Impact Assessment Review 24, no. 1 (January 1, 2004): 27-46, https://doi.org/10.1016/S0195-9255(03)00137-9.

${ }^{41}$ Henrik Lindhjem et al., "Environmental Economic Impact Assessment in China: Problems and Prospects," Environmental Impact Assessment Review 27, no. 1 (January 1, 2007): 1-25, https://doi.org/10.1016/j.eiar.2006.08.004.
} 
M Jahanzeb Butt, Yen Chiang Chang \& Khadija Zulfiqar

building in the new EIA regulations implemented in $2002 .{ }^{42}$ There are different chapters in EIA of 2002, for the infrastructure, construction and industrial projects.

\subsection{Reporting and Monitoring}

EPL ratifying the International Convention on Access to Information, Public Participation in Decision-Making and Access to Justice in Environmental Matters (Aarhus Convention) requires the disclosure and public involvement related to environmental protection. ${ }^{43}$ SEPA and Provincial Authorities are responsible for disclosing environmental quality and standards, including the permits, waste management, penalisation, fee-charging and usage issues. ${ }^{44}$ Industries discharging wastes are required to truthfully disclose the type and quantity of the pollutants, discharge methods, emission concentration, construction and operation of pollution prevention and control facilities. ${ }^{45}$

42 "Environmental Impact Assessment Law in China's Courts: A Study of 107 Judicial Decisions," Environmental Impact Assessment Review 55 (November 1, 2015): 35-44, https://doi.org/10.1016/j.eiar.2015.06.008.

${ }^{43}$ Guizhen He et al., "Changes and Challenges: China's Environmental Management in Transition," Environmental Development 3 (July 1, 2012): 25-38,

https://doi.org/10.1016/j.envdev.2012.05.005.

${ }^{44}$ Zhang and Wen, "Review and Challenges of Policies of Environmental Protection and Sustainable Development in China."

${ }^{45}$ Ibid., 
A Comparative Analysis of the Environmental Policies in China and...

Table 1: Environmental Laws and Regulations of China

\begin{tabular}{|c|c|c|}
\hline Year & Law & Implementing Authority \\
\hline 2015 & $\begin{array}{l}\text { Environmental Protection of } \\
\text { Law }\end{array}$ & SEPA, CPENR, COA, NDRC. \\
\hline 1995 & $\begin{array}{l}\text { The Law on the Prevention } \\
\text { and Control of } \\
\text { Environmental Pollution }\end{array}$ & $\begin{array}{l}\text { SEPA, Local and Provincial } \\
\text { Authorities, NDRC. }\end{array}$ \\
\hline 1984 & $\begin{array}{l}\text { The Law on the Prevention } \\
\text { and Control of Water } \\
\text { Pollution }\end{array}$ & $\begin{array}{l}\text { SEPA, COA, Ministry of } \\
\text { Agriculture. }\end{array}$ \\
\hline 2014 & $\begin{array}{l}\text { The Law on the Prevention } \\
\text { and Control of Atmospheric } \\
\text { Pollution }\end{array}$ & $\begin{array}{l}\text { SEPA, Department of } \\
\text { Change, Climate } \\
\text { Transportation, PTA. }\end{array}$ \\
\hline 1999 & $\begin{array}{l}\text { The Law on } \\
\text { Marine Environmental } \\
\text { Protection }\end{array}$ & $\begin{array}{l}\text { SEPA, SOA, PTA, } \\
\text { Ministry of Transportation. }\end{array}$ \\
\hline \multirow[t]{2}{*}{2002} & $\begin{array}{l}\text { EIA Regulations of } \\
1970-2002\end{array}$ & All the relevant departments \\
\hline & $\begin{array}{l}\text { Reporting and Monitoring } \\
\text { under EPL }\end{array}$ & All the relevant departments \\
\hline
\end{tabular}

Source: Compiled and prepared by Authors, data retrieved from the article of 'Zhilin $\mathrm{Mu}$, Shuchun $\mathrm{Bu}$, and Bing Xue. ${ }^{46}$

\section{Environmental Policy of Pakistan}

\subsection{Historical Perspective}

The competitive trade policies, cheap labour standards, and weak environmental law allowed rapid industrialisation in Pakistan during 1980 $-1999 .{ }^{47}$ International and national criticism moved the then federal

${ }^{46}$ Zhilin $\mathrm{Mu}$, Shuchun Bu and Bing Xue, "Environmental Legislation in China: Achievements, Challenges and Trends," Sustainability 6, no. 12 (December 2014): 8967-79, https://doi.org/10.3390/su6128967.

${ }^{47}$ Akbar Noman and Mir Annice Mahmood, "Industrial Development and Efficiency in Pakistan: A Revisionist Overview [with Comments]," The Pakistan Development Review 30, no. 4 (1991): 849-61. See also, Faisal Bari, "Pakistan's Industrialization Strategy," Presentation (Pakistan: Pakistan Development Forum and The World Bank, 2007), http://siteresources.worldbank.org/INTPAKISTAN/Resources/Presentation-by-faisalbari-sess-V.pdf. 


\section{Jahanzeb Butt, Yen Chiang Chang \& Khadija Zulfiqar}

government of Pakistan (federal government) in incorporating the Stockholm Declaration through the Pakistan Environmental Protection Ordinance (PEPO) of $1983 .{ }^{48}$ The PEPO established the Pakistan Environmental Protection Council (PEPC) as the first-ever environmental policymaking authority purported to establish the Environmental Protection Agency (EPA) as an environmental regulatory authority. ${ }^{49}$

The Rio Declaration and Biodiversity Convention impacted Pakistan's environmental policy, resulting into the '1992 National Conservation Strategy' ( $1^{\text {st }}$ Environmental Policy). ${ }^{50}$ First environmental policy was critical for PEPC in implementing the new 'Pakistan Environmental Protection Act (PEPA) of 1997' and functionalising the federal EPA. ${ }^{51}$ Newly promulgated PEPA restructured the PEPC and EPA with the purposes of environmental policymaking and implementation mechanisms. ${ }^{52}$ The members of PEPC are the prime minister, minister for environment, chief ministers of the provinces, minister for environment in the provinces or any other experts, academia or stakeholders. ${ }^{53}$ The PEPC

\footnotetext{
${ }^{48}$ Mujahida Naureen, "Development of Environmental Institutions and Laws in Pakistan," Pakistan Journal of History and Culture XXX, no. 1 (2009): 93-112.

${ }^{49}$ See: "Pakistan Environmental Protection Ordinance, 1983 no. 17(1)/83-Pub, Dated, 31 December, Enacted 1983 (Government of Pakistan)" (n.d.). Kamran Khan Khan, A Handbook on National Environmental Legislation and Institutions in Pakistan, 1st ed., South Asia Cooperation for Environment Programme (SACEP) - Under the Publication Series of SACEP Environmental Law and Policy (Colombo, Srilanka: South Asia Cooperation for Environment Programme (SACEP), 2009), http://www.sacep.org/pdf/Reports-Technical/2001-UNEP-SACEP-Law-HandbookPakistan.pdf. See also, Naureen, "Development of Environmental Institutions and Laws in Pakistan."

${ }^{50}$ Pakistan signed the Rio Declaration in 1992, see: "Review of Implementation of the Rio Principles," Study prepared by the Stakeholder Forum for a Sustainable Future, Detailed Review of Implementation of the Rio Principles (United Nations, UNDESA and UNEP, September 2011),

https://sustainabledevelopment.un.org/content/documents/1127rioprinciples.pdf.

${ }^{51}$ Section 5, "Pakistan Environmental Protection Act," Act No. XXXIV of 1997/No. F. 9(46)/97-Legis, Enforced by Pakistan Government, 1997 § (1997)., see also: "Information Provided by the Government of Pakistan to the United Nations Commission on Sustainable Development," Briefing Paper, Implementation of Agenda 21: Review of Progress Made since the United Nations Conference on Environment and Development, 1992 (New York: United Nations, February 26, 1997), https://www.un.org/esa/earthsummit/pakis-cp.htm.

52 See, Section 5 and 4, Pakistan Environmental Protection Act.

${ }^{53}$ Pakistan Environmental Protection Agency, Archives, "Brief on Pakistan Environmental Protection Act, 1997."
} 
A Comparative Analysis of the Environmental Policies in China and...

establishes guidelines or rules for the development and infrastructure projects under the PEPA, while devising an environmental threshold. ${ }^{54}$ The EPA is authorised to administer and regulate the projects proportional to environmental protection. The EPA establishes a national environmental co-ordination committee comprising the director-general as its chairman and the director generals of the provincial environmental protection agencies to exercise and perform functions for implementing the PEPA and respective environmental policies. ${ }^{55}$

After the $18^{\text {th }}$ Amendment in the Constitution, environmental protection was a devolved subject among the four provinces (i.e., Sindh, Punjab, Balochistan, Khyber Pakhtunkhwa), the two semi-autonomous regions (Azad Jammu and Kashmir, and Gilgit-Baltistan), and the federal capital (Islamabad). Each province or territory is independently authorised to make its environmental laws and policies owing to the national framework's umbrella. ${ }^{56}$ There are now four provincial, two autonomous, and one federal environmental agencies with their own set of rules and regulations. ${ }^{57}$

The federal government established the Provincial Conservation Strategy in 1996, ( $2^{\text {nd }}$ Environmental Policy), with the specific purpose of developing an inter/intra-coordination mechanism among the provincial, semi-autonomous and federal government. ${ }^{58}$ The provinces and semiautonomous regions laid down their own legislation, namely, the Punjab Environmental Protection Act, ${ }^{59}$ Sindh Environmental Protection Act, ${ }^{60}$

\footnotetext{
${ }^{54}$ Section 4, Pakistan Environmental Protection Act.

${ }^{55}$ Section 6, Pakistan Environmental Protection Act.

${ }^{56}$ Hassan, "Environmental Law of Pakistan." See also: "Environmental Protection and the Eighteenth Amendment," Impact of Constitutional Amendments on Environmental Protection Legislation, Analysis of Laws in Force, and Assessment of Implementation Issues (Islamabad, Pakistan: International Union for Conservation of Nature (IUCN), Netherland Commission for Environmental Assessment and Government of Pakistan Ministry of Environment, May 19, 2012),

https://www.iucn.org/sites/dev/files/import/downloads/pk_niap_impact_of_18th_amd_ final_draft__19_may_2012_formatted.pdf.

${ }^{57}$ Naureen, "Development of Environmental Institutions and Laws in Pakistan."

58 "Pakistan's National Conservation Strategy: Renewing Commitment to Action," Review and Analysis (Islamabad, Pakistan: International Union for Conservation of Nature (IUCN), November 2000), https://www.iucn.org/downloads/pakistan_ncs_mid_review.pdf.

59 "Punjab Environmental Protection Act, 1997 (XXXIV of 1997) Amended Upto Act XXXV of 2012, Enacted in 2012 (Government of Punjab, Pakistan)" (n.d.).
} 
M Jahanzeb Butt, Yen Chiang Chang \& Khadija Zulfiqar

Balochistan Environment Protection Act, ${ }^{61}$ Khyber-Pakhtunkhwa Environmental Protection Act, ${ }^{62}$ Azad Jammu and Kashmir Environmental Protection $\mathrm{Act}^{63}$ and Gilgit Baltistan Environmental Protection Act. ${ }^{64}$

\subsection{EIA and Initial Environmental Examination (IEE)}

IEE and EIA Regulations empowers the EPA(s) to provide sectoral guidelines and specific assessment mechanisms for infrastructure and construction industries. ${ }^{65} \mathrm{EPA}(\mathrm{s})$ are the agencies to conduct IEE and EIA prior to the approval of any infrastructure or construction project. ${ }^{66}$ Further, there are public participation mechanisms, transparency and monitoring as entailed in the IEE and EIA under the Aarhus Convention to which Pakistan is a party. ${ }^{67}$

\subsection{National Environmental Quality Standards Regulations (NEQS)}

NEQS of 1993 related to the municipal and liquid industrial effluents were implemented under the PEPO framework and later amended according to UNFCCC through PEPA. ${ }^{68}$ NEQS regulates liquid waste, industrial and transportation emissions, and noise pollution. The NEQS Regulations, including the air pollution control mechanisms and

60 "Sindh Environmental Protection Act, 2014 (No. PAS/Legis-B-06/2014) Enacted 2014 (Government of Pakistan)" (n.d.).

61 "The Balochistan Environment Protection Act, 2012, (No. PAB/Legis: V (9)/2013), Enacted 2013 (Government of Baluchistan)" (n.d.).

62 "The Khyber Pakhtunkhwa Environmental Protection Act, 2014 (Khyber Pakhtunkhwa Act No. XXXVIII of 2014) Enacted 2014 (Government of Khyber Pakhtunkhwa, Pakistan)" (n.d.).

63 "Azad Jammu and Kashmir Environmental Protection Act, 2000 (No. 696702/Leg/2000) Enacted 2000 (Government of Azad Jammu and Kashmir, Pakistan)" (n.d.).

${ }^{64}$ Lau, "The Role of Environmental Tribunals in Pakistan." See also, Dr Shafiq-urRehman, "The Case for Environmental Governance," Dawn, June 24, 2018, sec. Archives. And Agency, "Gilgit-Baltistan Environmental Protection Agency," Pakistan Today (blog), January 29, 2017, https://www.pakistantoday.com.pk/tag/gilgit-baltistanenvironmental-protection-agency/.

${ }^{65}$ Regulation 6, "Pakistan Environmental Protection Agency (Review of IEE and EIA) Regulations, 2000" (2001).

${ }^{66}$ Regulation 7 - 10, Pakistan Environmental Protection Agency (Review of IEE and EIA) Regulations, 2000.

${ }^{67}$ Regulation 10 (Public Participation) Pakistan Environmental Protection Agency (Review of IEE and EIA) Regulations, 2000.

${ }^{68}$ See also: "National Environmental Quality Standards for Municipal and Liquid Industrial Effluents, 1993," Enforced 1995, Part - II, 1995, M-302, L - 7646 § (n.d.). Naureen, "Development of Environmental Institutions and Laws in Pakistan." 
A Comparative Analysis of the Environmental Policies in China and...

Provincial NEQS for Motor Vehicle Exhaust and Noise, are adopted by provincial EPA's following the federal EPA. ${ }^{69}$

\subsection{Pakistan Climate Change Act and the Ministry of Climate Change} In 2012, the Ministry of Environment was restructured and renamed as Ministry of Climate Change (the Ministry), considering signing and ratifying the UNFCCC and the Kyoto Protocol. ${ }^{70}$ The Ministry was designated with a task force to develop a new climate change policy considering all kind of environmental threats, including air, terrestrial and marine. $^{71}$ Thereafter, the National Climate Change Policy (Climate Change Policy) for the Ministry operations was established in 2014, with a 15-year plan of implementation in developing coordination among provinces, autonomous regions, and the federal capital, establishing NEQS Regulations for Ambient Air. ${ }^{72}$ This Policy replaced the previous

69 "Punjab Environmental Quality Standards for Ambient Air, 2016, no. SO(G)/EPD/726/2013, 2016 (Government of Punjab, Pakistan)" (n.d.). See also: "Sindh

Environmental Industrial Waste Water, Effeluent, Domestic, Sewerage, Industrial Air Emissions and Ambient Airs, 2014, no. EPA/TECH/739/2014, 2014 (Government of Sindh, Pakistan)" (n.d.).

${ }^{70}$ The Ministry's jurisdiction is extended by the EPA's placement, accompanied by the National Disaster Management Authority, Zoological Survey Department and Global Change Impact Study Centre (newly established).

"Arrangements for Intergovernmental Meetings," Brief, Subsidiary Body for Impementation of UNFCCC (United Nations, June 20, 1997), https://unfccc.int/resource/docs/1997/sbi/15.pdf., Jawed Ali Khan, Murtaza Malik, and Irfan Anjum, "Implementation of UN Framework Convention on Climate Change in Pakistan," in Letter to Respectively, Director General (Environment); Program Manager (Policy Coordination and Environmental Governance) and Section Officer, Ministry of Environment, Islamabad, Pakistan. (Proc. Capacity Building Workshop on Global Change Research, Asia Pacific Network for Global Change Research, Japan and AgroDev International, Islamabad, Pakistan: Islamabad Papers, 2004), 65-69, https://www.researchgate.net/publication/289671404.

${ }^{71}$ Ministry of Climate Change, Archives, "Achievements of the Ministry of Climate Change" (Islamabad, Pakistan: Government of Pakistan, March 2, 2018), http://mocc.gov.pk/moclc/userfiles1/file/Final\%20Report\%20MOCC\%20-2\%20years\%2005_10_2015\%20(1).pdf. See also, Toqeer Ahmed et al., "Water-Related Impacts of Climate Change on Agriculture and Subsequently on Public Health: A Review for Generalists with Particular Reference to Pakistan," International Journal of Environmental Research and Public Health 13, no. 11 (2016): 1051, https://doi.org/10.3390/ijerph13111051.

72 "National Environmental Quality Standards for Ambient Air, 2010, S.R.O 1062(1)/2010, under Section 6 of the Pakistan Environmental Protection Act, 1997, Enacted 2010 (Government of Pakistan" (2010). See also: Muhammad Mumtaz, "The National Climate Change Policy of Pakistan: An Evaluation of Its Impact on Institutional 


\section{Jahanzeb Butt, Yen Chiang Chang \& Khadija Zulfiqar}

$2^{\text {nd }}$ Environmental Policy and advances international and regional cooperation, recognising climate change as a global concern. ${ }^{73}$ The primary concern of this policy is droughts and floods faced by the country over the past 12-15 years. Furthermore, it also recognises mountains, rangelands, arid, coastal and wetlands ecosystems and their disruptions through energy, town, industrial and infrastructural development. ${ }^{74}$

The Ministry under the Climate Change Policy also urges to seek environment-friendly, sustainable and renewable technological development. $^{75}$ Moreover, the Ministry provides the measures in developing integrated mechanisms of governing the environment and climate while conducting stakeholder consultations. The Ministry involves the provincial and local governments, economic, education and publicprivate stakeholders for consultations. ${ }^{76}$ Recently the ministry also established a Climate Change Policy Implementation Committees for monitoring and enforcement at local levels in each province and autonomous regions.

In 2017, another impactful climate change legislation inducted under the Climate Change Policy was Pakistan Climate Change Act (Climate Change Act),${ }^{77}$ meant to purview the environment from a holistic approach and by engendering more coordination among the provincial and federal governments. ${ }^{78}$ Therefore, the Pakistan Climate Change Council (CCC) under the Climate Change Act is composed of the Federal Minister for Climate Change, the Provincial Chief Ministers, Chairman of the National Disaster Management Authority, Members of the Chambers of Commerce and other stakeholders, including researchers, academia and

Change," Earth Systems and Environment 2, no. 3 (December 1, 2018): 525-35, https://doi.org/10.1007/s41748-018-0062-x.

${ }^{73}$ Asad Abbas Maken, "Why Pakistan Needs a Climate Change Financing Framework?," Policy Breif (Islamabad, Pakistan: United Nations Development Programme, Pakistan, 2014), https://www.adaptation-undp.org/explore/pakistan.

${ }^{74}$ Khan, Malik and Anjum, "Implementation of UN Framework Convention on Climate Change in Pakistan."

${ }^{75}$ Asad Abbas Maken, "Why Pakistan Needs a Climate Change Financing Framework?"

${ }^{76}$ Ministry of Climate Change, Archives, "Achievements of the Ministry of Climate Change."

77 "Pakistan Climate Change Act, 2017, no. F. 9(4)/2017-Legis, Enacted 2017 (Government of Pakistan)" (n.d.).

${ }^{78}$ Khan, Malik and Anjum, "Implementation of UN Framework Convention on Climate Change in Pakistan." 
A Comparative Analysis of the Environmental Policies in China and...

the scientists. The Climate Change Act also establishes Pakistan Climate Change Authority (CCA) with provincial and federal memberships for its effective implementation at provincial and local levels. ${ }^{79}$

\subsection{Secondary Legislation}

As mentioned above, the provinces in Pakistan are empowered to promulgate rules and regulations pertaining to the national and provincial environmental policy jurisdiction. $^{80}$ For example, in 2001, the Environmental Sample Rules (ESR) ${ }^{81}$ were enacted to inspect industrial units for any violation of NEQS Regulations. Similarly, the Pakistan Biosafety Rules of $2005,^{82}$ Hospital Waste Management Rules and the Handling, Manufacture, Storage, Import of Hazardous Waste and Hazardous Substances Rules, ${ }^{83}$ and National Forest Policy ${ }^{84}$ are among other regulations of EPA. ${ }^{85}$ Forest policy is pertinent due to infrastructure development, as the measures reconsidered in this policy are to revive the forests while conducting strict EIA and Environmental Management Plan. ${ }^{86}$ There are proposals to include the developing projects such as large dams, road and rail networks in the EIA procedures. The forest policy calls for coordination among the existing forests departments in the

${ }^{79}$ Section 5 - 8, Pakistan Climate Change Act, 2017, no. F. 9(4)/2017-Legis, enacted 2017 (Government of Pakistan).

${ }^{80}$ Khan, A Handbook on National Environmental Legislation and Institutions in Pakistan.

81 "Environmental Sample Rules, 2001, S.R.O 527(1)/2001, Enacted 2001 (Government of Pakistan)" (n.d.).

82 "Pakistan Biosafety Rules, 2005, S.R.O (I) 336(I)/2005, Enacted 2005 (Government of Pakistan)" (n.d.).

83 “Hospital Waste Management Rules, 2005 S.R.O 1013(1)/2005, Enacted 2005

(Government of Pakistan)" (n.d.).

${ }^{84}$ Bashir Ahmed Wani, "National Forest Policy Review" (Islamabad, Pakistan: Food and Agriculture Organization and Ministry of Environment, Local Government and Rural Development, Pakistan, n.d.), http://www.fao.org/tempref/docrep/fao/005/AC921E/AC921E08.pdf.

${ }^{85}$ Hospital Waste Management Rules, 2005 S.R.O 1013(1)/2005, enacted 2005 (Government of Pakistan).

${ }^{86}$ Babar Shahbaz, Tanvir Ali and Abid Qaiyum Suleri, "A Critical Analysis of Forest Policies of Pakistan: Implications for Sustainable Livelihoods," Mitigation and Adaptation Strategies for Global Change 12, no. 4 (2007): 441-53., Bashir Ahmed Wani, "National Forest Policy Review"; Aamir Saeed, August 21, and 2015, "Pakistan Unveils First National Forest Policy without Provincial Government Support |The Third Pole," accessed March 9, 2020, https://www.thethirdpole.net/en/2015/08/21/pakistanunveils-first-national-forest-policy-without-provincial-government-support/. 
M Jahanzeb Butt, Yen Chiang Chang \& Khadija Zulfiqar

provinces, autonomous regions and federal capital for effective implementation. ${ }^{87}$

Table 2: Environmental Law and Regulations of Pakistan

\begin{tabular}{|c|c|c|}
\hline Year & $\begin{array}{l}\text { Legislation and Policies } \\
\text { (Rules and Regulations) }\end{array}$ & Establishment/Institutions \\
\hline 1983 & $\begin{array}{l}\text { Pakistan Environmental } \\
\text { Protection Ordinance }\end{array}$ & $\begin{array}{l}\text { Ministry of Environment } \\
\text { Pakistan Environmental Protection } \\
\text { Council }\end{array}$ \\
\hline 1992 & $\begin{array}{l}\text { National Conservation } \\
\text { Strategy (Environmental } \\
\text { Policy - I) }\end{array}$ & $\begin{array}{l}\text { Ministry of Environment } \\
\text { Pakistan Environmental Protection } \\
\text { Council }\end{array}$ \\
\hline 1993 & $\begin{array}{l}\text { National Environmental } \\
\text { Quality Standards Regulations } \\
\text { Related to the Municipal and } \\
\text { Liquid Industrial Effluents }\end{array}$ & $\begin{array}{l}\text { Pakistan Environmental Protection } \\
\text { Agency }\end{array}$ \\
\hline 1996 & $\begin{array}{l}\text { Provincial Conservation } \\
\text { Strategy (Environmental } \\
\text { Policy - II) }\end{array}$ & Provincial Environmental Departments \\
\hline 1997 & $\begin{array}{l}\text { Pakistan Environmental } \\
\text { Protection Act }\end{array}$ & $\begin{array}{l}\text { Pakistan Environmental Protection } \\
\text { Agency (Functional) }\end{array}$ \\
\hline 2000 & $\begin{array}{l}\text { Environmental Impact } \\
\text { Assessment and Initial } \\
\text { Environmental Examination } \\
\text { Rules }\end{array}$ & $\begin{array}{l}\text { Provincial Ministries, Division, or } \\
\text { Department of Environment. }\end{array}$ \\
\hline 2001 & Environmental Sample Rules & $\begin{array}{l}\text { Provincial Ministries, Division, or } \\
\text { Department of Environment. }\end{array}$ \\
\hline 2005 & Pakistan Biosafety Rules & $\begin{array}{l}\text { Provincial Ministries, Division, or } \\
\text { Department of Environment. }\end{array}$ \\
\hline 2005 & $\begin{array}{l}\text { The Hospital Waste } \\
\text { Management Rules }\end{array}$ & $\begin{array}{l}\text { Provincial Ministries, Division, or } \\
\text { Department of Environment. }\end{array}$ \\
\hline 2005 & $\begin{array}{l}\text { National Environmental } \\
\text { Policy (Environmental Policy } \\
\text { - III) }\end{array}$ & $\begin{array}{l}\text { National Environment Policy } \\
\text { Implementation Committee }\end{array}$ \\
\hline 2010 & $\begin{array}{l}\text { National Environmental } \\
\text { Quality Standards for Ambient } \\
\text { Air }\end{array}$ & $\begin{array}{l}\text { Provincial Ministries, Division, or } \\
\text { Department of Environment }\end{array}$ \\
\hline $\begin{array}{l}2010 \\
2012\end{array}$ & $\begin{array}{l}18^{\text {th }} \text { Amendment } \\
\text { The Balochistan Environment } \\
\text { Protection Act } \\
\text { The Punjab Environmental } \\
\text { Protection Act, } 1997 \text { (As }\end{array}$ & $\begin{array}{l}\text { Provincial Ministries, Division, or } \\
\text { Department of Environment. } \\
\text { Balochistan Environment Protection } \\
\text { Agency } \\
\text { Punjab Environmental Protection }\end{array}$ \\
\hline
\end{tabular}

${ }^{87}$ E. Aftab and G.M. Hickey, "Forest Administration Challenges in Pakistan: The Case of the Patriata Reserved Forest and the 'New Murree' Development," The International Forestry Review 12, no. 1 (2010): 97-105. 
A Comparative Analysis of the Environmental Policies in China and...

\begin{tabular}{|l|l|l|}
\hline & $\begin{array}{l}\text { amended) } \\
\text { The Khyber Pakhtunkhwa } \\
\text { Environmental Protection Act } \\
\text { The Sindh Environmental } \\
\text { Protection Act }\end{array}$ & $\begin{array}{l}\text { Agency } \\
\text { Khyber Pakhtunkhwa Environmental } \\
\text { Protection Agency } \\
\text { The Sindh Environmental Protection } \\
\text { Agency }\end{array}$ \\
\hline $\mathbf{2 0 1 2}$ & $\begin{array}{l}\text { National Climate Change } \\
\text { Policy }\end{array}$ & $\begin{array}{l}\text { Ministry of Climate Change } \\
\text { National Climate Change Policy } \\
\text { Implementation Committee } \\
\text { Provincial Climate Change Policy } \\
\text { Implementation Committee }\end{array}$ \\
\hline $\mathbf{2 0 1 5}$ & $\begin{array}{l}\text { National Forests Policy } \\
\text { (Revival of Forests Act, 1927) }\end{array}$ & $\begin{array}{l}\text { Integration of existing Forest } \\
\text { Departments under Federal Forestry } \\
\text { Board }\end{array}$ \\
\hline $\mathbf{2 0 1 6}$ & $\begin{array}{l}\text { The Handling, Manufacture, } \\
\text { Storage, Import of Hazardous } \\
\text { Waste and Hazardous } \\
\text { Substances Rules }\end{array}$ & $\begin{array}{l}\text { Pakistan Climate Change Act, } \\
\text { 2017 }\end{array}$ \\
\hline $\mathbf{2 0 1 7}$ & $\begin{array}{l}\text { Pakistan Climate Change Council and } \\
\text { Pakistan Climate Change Authority }\end{array}$ \\
\hline
\end{tabular}

Source: Compiled and Arranged by Authors, material retrieved from the book of Justice Jawad Hassan, the data available on the official websites of Environmental Protection Agencies of Pakistan, and Ministry of the Climate Change. ${ }^{88}$

\section{Comparative Analysis of Environmental Laws and Policies in China and Pakistan}

An effective environmental governance mechanism in any state largely depends upon uniform and well-integrated policy involving the various official organs, civil society clusters and the wide variety of stakeholders, all cognisant of the benefits and obligations accompany developmental projects. China's environmental policy, although not fully integrated, is a good example for countries like Pakistan to follow. There is uniformity and specific implementation through capacitated authorities at provincial and local levels. The old policies and laws are often revised in order to remove irregularities and implementation takes place more effectively. ${ }^{89}$

\footnotetext{
${ }^{88}$ Jawad Hassan, Environmental Laws of Pakistan: With the Exhaustive Commentary on the Pakistan Environmental Protection Act, 1997, Containing All Rules, Regulations, Latest Case Law and Treaties (Book Biz, 2006). See: Ministry of Climate Change,

Pakistan http://www.mocc.gov.pk/

${ }^{89}$ United Nations Environment Programme, Global Environment Outlook 3: Past, Present and Future Perspectives (Earthscan, 2002). See also, Naoko, "Environmental and Social Management Plan" (The World Bank, July 22, 2015),
} 


\section{Jahanzeb Butt, Yen Chiang Chang \& Khadija Zulfiqar}

The SEPA is responsible for coordination, monitoring and evaluation, as well as controlling and preventing waste dumping comprehensively. Furthermore, it supervises the legislation, policy and implementation of environmental strategies under international commitments with local and provincial interests.

Conversely, in Pakistan, the environmental governance mechanisms often remain complicated and more ambiguity has crept in following the induction of the $18^{\text {th }}$ Amendment, devolving powers and accountability to provincial governments. ${ }^{90}$ This devolution in the provinces seems to have been made without any principal and overarching policy mechanisms in the centre. From 2005 to 2012, the National (Federal) Environmental Policy has been upgraded without adopting new and substantive policy mechanisms. ${ }^{91}$ Such irregularities on the part of the $2^{\text {nd }}$ Environmental policy, which intended to develop EIA, ${ }^{92}$ have rather proved to be impractical..$^{93}$ As shown in Table - 3, in 2000, a detailed version of EIA along with the IEE was established under the PEPA empowering EPAs. ${ }^{94}$ The NEQS Regulations on industrial and motor-vehicle correspondingly were revised with more stringent regulations being placed to promote environment-friendly transportation..$^{95}$ However, most of the regulations lack effective implementation because they require coordination among and across the provincial and federal departments or authorities.

\section{Table 3: Rules and Regulations of the Provinces and Semi- Autonomous Regions of Pakistan}

Provinces: Punjab, Sindh, Balochistan and Khyber-Pakhtunkhwa Autonomous Regions: Azad Kashmir and Gilgit-Baltistan

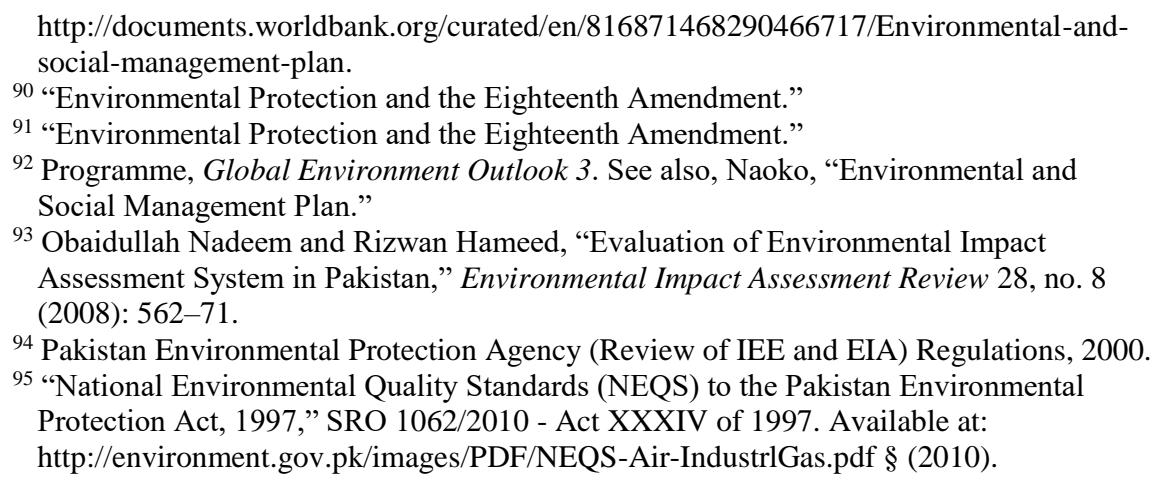

${ }^{93}$ Obaidullah Nadeem and Rizwan Hameed, "Evaluation of Environmental Impact Assessment System in Pakistan," Environmental Impact Assessment Review 28, no. 8 (2008): 562-71.

${ }^{94}$ Pakistan Environmental Protection Agency (Review of IEE and EIA) Regulations, 2000.

95 "National Environmental Quality Standards (NEQS) to the Pakistan Environmental Protection Act, 1997," SRO 1062/2010 - Act XXXIV of 1997. Available at: http://environment.gov.pk/images/PDF/NEQS-Air-IndustrlGas.pdf § (2010). 
A Comparative Analysis of the Environmental Policies in China and...

\begin{tabular}{|c|c|c|}
\hline Sr.No & $\begin{array}{l}\text { Provincial and Autonomous } \\
\text { Regions Environmental Rules and } \\
\text { Regulations }\end{array}$ & Purpose \\
\hline 1. & $\begin{array}{l}\text { Environmental Protection } \\
\text { (Delegation of Powers for } \\
\text { Environmental Approvals) Rules }\end{array}$ & $\begin{array}{l}\text { To coordinate with local administration for } \\
\text { monitoring and implementation }\end{array}$ \\
\hline 2. & $\begin{array}{l}\text { Environmental Protection Council } \\
\text { (Procedure) Rules }\end{array}$ & To make environmental policy \\
\hline 3. & $\begin{array}{l}\text { Environmental Quality Standards } \\
\text { for Municipal and Liquid Industrial } \\
\text { Effluents }\end{array}$ & To regulate industrial effluents \\
\hline 4. & $\begin{array}{l}\text { Environmental Quality Standards } \\
\text { for Motor Vehicle Exhaust and } \\
\text { Noise and Environmental Protection } \\
\text { Motor Vehicles Rules }\end{array}$ & $\begin{array}{l}\text { To minimise and eradicate the pollution from } \\
\text { vehicles }\end{array}$ \\
\hline 5. & $\begin{array}{l}\text { Environmental Quality Standards } \\
\text { for Ambient Air }\end{array}$ & To minimise and eradicate air pollution \\
\hline 6. & $\begin{array}{l}\text { Environmental Quality Standards } \\
\text { for Noise }\end{array}$ & To minimise and eradicate voice pollution \\
\hline 7. & $\begin{array}{l}\text { Environmental Quality Standards } \\
\text { for Treatment of Liquid and } \\
\text { Disposal of Bio-medical Waste }\end{array}$ & To regulate biomedical waste \\
\hline 8. & $\begin{array}{l}\text { Environmental Quality Standards } \\
\text { for Industrial Gaseous Emissions }\end{array}$ & To regulate industrial gases and emissions \\
\hline 9. & Bio-safety Rules & To regulate Biological substances and labs \\
\hline 10. & Hospital Waste Management Rules & To regulate and manage hospital waster \\
\hline 11. & Environmental Samples Rules & To search and inspect industries \\
\hline 12. & $\begin{array}{l}\text { Environmental Quality Standards } \\
\text { Self-Monitoring and Reporting by } \\
\text { Industry Rules }\end{array}$ & For self-reporting by industrial units \\
\hline 13. & IEE \& EIA Regulations & $\begin{array}{l}\text { For the conduct of initial environmental } \\
\text { examination and environmental impact } \\
\text { assessment }\end{array}$ \\
\hline
\end{tabular}

Source: Compiled and Arranged by Authors, material retrieved from the official websites of the Punjab, Sindh, Balochistan, KPK, Gilgit-Baltistan and Kashmir EPA (s) ${ }^{96}$

\footnotetext{
${ }^{96}$ The details of the material can be accessed through the websites: (https://pitb.gov.pk/epd), Sindh EPA (http://epasindh.gov.pk/), Balochistan EPA (https://balochistan.gov.pk/), Khyber-Pakhtunkhwa (https://epakp.gov.pk/), SemiAutonomous Regions EPA (https://ajkppra.gov.pk/) and (http://gilgitbaltistan.gov.pk/). (Last accessed 12 December 2020).
} 


\section{Jahanzeb Butt, Yen Chiang Chang \& Khadija Zulfiqar}

On the contrary, in China, the policy mechanisms integrate the SEPA with provincial and local administration via reporting and monitoring mechanisms. The LCPEP empowers the SEPA to coordinate with provincial, local and relevant authorities and implement in an accompanying manner. The environmental policy of China further establishes mechanisms of horizontal and vertical integration. ${ }^{97}$ LMEP is a classic example, authorising the SOA to coordinate with PTA and Maritime Safety Administration under the Ministry of Transport, and Administration of Fishery and Fishing Harbour Supervision, directly under the Ministry of Agriculture. ${ }^{98}$

The environmental law of Pakistan authorises the authorities to inspect under specific regulations for any violation. The main barrier for any such inspection is with a condition, i.e., 'reasonable ground. ${ }^{99}$ The authorised official of the EPA(s), in case of any violation, has to write a complaint to the highest official (Directorate General) of EPA(s) for further actions along with the samples of environmental degradation as evidence. ${ }^{100}$ More confusion arises when it comes to inspection or search, as both have different meaning and objectives. ${ }^{101}$ Any search or inspection is carried under the criminal procedure law and is conditional on obtaining a search warrant from the environmental magistrate. ${ }^{102}$

\section{Evaluating CPEC Projects under Environmental Policy Framework of China and Pakistan}

The CPEC, under the BRI framework, commenced with a Memorandum of Understanding (MOU) of 2013 between China and Pakistan to operationalise their BIT and FTAs. ${ }^{103}$ The CPEC, previously administered

\footnotetext{
${ }^{97}$ He et al., "Changes and Challenges."

${ }^{98}$ Chang, "A Note on a Comparison of the Ocean Governance System Between Mainland China and Taiwan."

${ }^{99}$ Rule 4, Environmental Sample Rules, 2001, S.R.O 527(1)/2001, enacted 2001 (Government of Pakistan).

${ }^{100}$ Rule 4, Environmental Sample Rules, 2001, S.R.O 527(1)/2001, enacted 2001 (Government of Pakistan).

${ }^{101}$ Rule 5, Environmental Sample Rules, 2001, S.R.O 527(1)/2001, enacted 2001 (Government of Pakistan).

102 Environmental Sample Rules, 2001, S.R.O 527(1)/2001, enacted 2001 (Government of Pakistan).

103 “Agreement Between the Government of the People's Republic of China and The Government of the Islamic Republic of Pakistan on the Reciprocal Encouragement and Protection of Investment," Signed: 12-02-1989, Came into force: 30-09-1990
} 
A Comparative Analysis of the Environmental Policies in China and...

by the Ministry of Planning Development and Reform (Ministry of Planning) and the Board of Investment (BOI), is now attaining the harvesting phase. ${ }^{104} \mathrm{~A}$ newly-established special authority, 'the ChinaPakistan Economic Corridor Authority (CPEC Authority)', is now going to take the sole responsibility of CPEC projects. ${ }^{105}$ Primarily, the CPEC Authority, falling under the direct control of the federal government, is expected to implement the CPEC projects on a priority basis. CPEC Authority is empowered to integrate any project's environmental and social impacts at any later stage while initially commencing them without any intervention by any regulatory authority. ${ }^{106}$

\subsection{Environmentally Unsustainable Power Generation Projects}

Under the Ministry of Energy handling the power generation projects, the Power Division places renewable energy in the Alternative Energy Development Board (AEDB) domain, and non-renewable energy rests with the Private Power and Infrastructure Board (Power Board). ${ }^{107}$ The National Electric Power Regulatory Authority (NEPRA), established in 1997 through the Regulation of Generation, Transmission and Distribution of Electric Power Act of 1997 (RGTDEPA), is the principal regulatory authority of power generation and supply. ${ }^{108}$

NEPRA mainly regulates the safety, tariffs, distribution and supply of the power generation and is empowered to enact and has enacted rules

(https://investmentpolicy.unctad.org/international-investment-agreements/treaty-

files/5660/download) $\S$ (n.d.). See also, Khaleeq Kiani, "International Arbitration Treaty

May Be a Trap for Pakistan,” Dawn, June 13, 2018, sec. Pakistan.

${ }^{104}$ Asif H. Qureshi, "China/Pakistan Economic Corridor: A Critical National and

International Law Policy Based Perspective," Chinese Journal of International Law 14, no. 4 (December 1, 2015): 777-99, https://doi.org/10.1093/chinesejil/jmv045.

105 Aamir Yasin, "Asim Bajwa Made Chairman of Newly Created CPEC Authority,"

Dawn, November 27, 2019, https://www.dawn.com/news/1519047. See also: China

Pakistan Economic Corridor Authority Ordinance, 2019, Ordinance No XII of 2019, enacted 2019 (Government of Pakistan). See also: "China Pakistan Economic Corridor Authority Ordinance, 2019, Ordinance No XII of 2019, Enacted 2019 (Government of Pakistan)" (n.d.).

${ }^{106}$ Section 4, China Pakistan Economic Corridor Authority Ordinance, 2019, Ordinance No XII of 2019, enacted 2019 (Government of Pakistan).

107 Shebonti Ray Dadwal and Chithra Purushothaman, "CPEC in Pakistan's Quest for Energy Security,” Strategic Analysis 41, no. 5 (2017): 515-24.

108 "Regulation of Generation, Transmission and Distribution of Electric Power Act," Act No. XL Of 1997/No. F, 22(23)/2017 § (1997). 


\section{Jahanzeb Butt, Yen Chiang Chang \& Khadija Zulfiqar}

and regulations. ${ }^{109}$ Although, the environmental regulation is also in the domain of the NEPRA as directed by the EPA yet, to date, NEPRA has not enacted any specific rules and regulations for the environment. The NEPRA and the Power Board refused the EPA's attempts to conduct the IEE and EIA for the on-going projects because of the urgency to install the power generation, supply lines and transmission projects required for Pakistan, which was at that time in deep crisis of power supply. ${ }^{110}$

The main threat through these coal power projects due to emissions (mainly greenhouse gases) is still an unregulated segment in Pakistan's overall ecological regime and environmental paradigms. ${ }^{111}$ In the province of Sindh, the major coal-power generation plants under CPEC will be based in Thar, generating about 3000-megawatts of electricity, and one in Karachi for the generation of 1320-megawatts. ${ }^{112}$ A 300-megawatt plant is under construction in Gwadar within the Balochistan EPA's jurisdictional limits whereas another plant of 1300-megawatt is in the development phase in Sahiwal within the jurisdictional scope of Punjab's EPA. The NEQS Regulations for Ambient Air established under the Climate Change Policy and Climate Change Act, apply to these coal projects and both the provincial and federal EPA(s) are empowered to inspect these projects. ${ }^{113}$

\footnotetext{
${ }^{109}$ Section 7, Regulation of Generation, Transmission and Distribution of Electric Power Act.

${ }^{110}$ Erica Downs, "China-Pakistan Economic Corridor Power Projects: Insights into Environmental and Debt Sustainability" (New York, NY: SIPA Centre on Global Energy Policy, October 2019), https://www.energypolicy.columbia.edu/research/report/chinapakistan-economic-corridor-power-projects-insights-environmental-and-debtsustainability. See also: Dr. Abdul Rauf, "Environmental Impact Assessment of CPEC Projects and Mitigation Strategy," Pakistan Observer (blog), August 23, 2019, https://pakobserver.net/environmental-impact-assessment-of-cpec-projects-andmitigation-strategy/.

${ }^{111}$ Dr. Abdul Rauf, "Environmental Impact Assessment of CPEC Projects and Mitigation Strategy," Pakistan Observer (blog), August 23, 2019. https://pakobserver.net/environmental-impact-assessment-of-cpec-projects-andmitigation-strategy/.

112 Shah Meer Baloch, “CPEC's Environmental Toll," News, The Diplomat (blog), April 18, 2018, https://thediplomat.com/2018/04/cpecs-environmental-toll/.

${ }^{113}$ Under Pakistan Environmental Protection Agency (Review of IEE and EIA) Regulations, 2000. See: Dadwal and Purushothaman, "CPEC in Pakistan's Quest for Energy Security."
} 


\section{A Comparative Analysis of the Environmental Policies in China and...}

These projects are commencing without IEE and EIA due to their specific priority under the CPEC legal framework. ${ }^{114}$

Implementation of the environmental framework (laws and governance) on power generation projects through EIA or IEE before initiation, lacks due to the missing linkages and coordination and overlapping jurisdiction among the EPA(s), NEPRA and PPIB. ${ }^{115}$ The overlapping jurisdiction among the provincial and central EPA(s) is confused with the specific application of environmental protection provisions. The federal domain projects, i.e., Power Board and NEPRA implementing their regulations, do not empower the provincial EPA(s) for IEE or EIA conduct.

Table 4: Coal Based Power Projects and Environmental Regulation

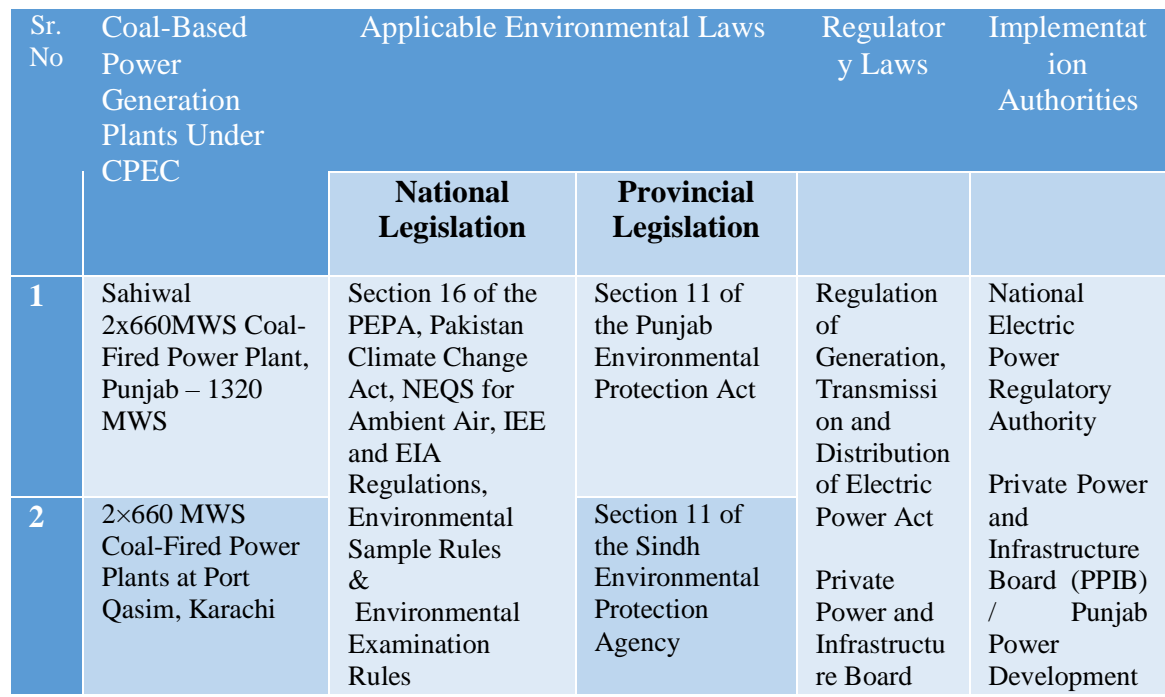

\footnotetext{
${ }^{114}$ Erica Downs, "China-Pakistan Economic Corridor Power Projects: Insights into Environmental and Debt Sustainability."

${ }^{115}$ Muhammad Naveed Iftikhar et al., "The Institutional and Urban Design of Gwadar City," Analytical (International Growth Centre, UK Aid, London School of Economics, Available at: https://www.theigc.org/wp-content/uploads/2019/05/Iftikhar-et-al-2019Final-report.pdf, 2019).
} 
M Jahanzeb Butt, Yen Chiang Chang \& Khadija Zulfiqar

\begin{tabular}{|c|c|c|c|}
\hline $\begin{array}{l}\text { Thar Power } \\
\text { Generation } \\
\text { Project:Surface } \\
\text { Mine in Block II } \\
\text { of Thar Coal } \\
\text { Field, 3.8 Million } \\
\text { tons/year, Engro } \\
\text { 2x330mw, Thar } \\
\text { Coal Power } \\
\text { Project, SSRL } \\
\text { Thar Coal Block-I } \\
\text { 6.8 (2×660MW), } \\
\text { Surface Mine in } \\
\text { Block II of Thar } \\
\text { Coal Field, } 3.8 \\
\text { Million tons/year }\end{array}$ & $\begin{array}{l}\text { Section } 11 \text { of } \\
\text { the Sindh } \\
\text { Environmental } \\
\text { Protection } \\
\text { Agency }\end{array}$ & Act 2012 & $\begin{array}{l}\text { Board } \\
\text { (PPDB) }\end{array}$ \\
\hline
\end{tabular}

Source: Compiled and prepared by Authors, data retrieved from 'China-Pakistan Economic Corridor Official Website and Report of Erica Downs. ${ }^{116}$

\subsection{Environmentally Unsustainable Infrastructure Projects}

The infrastructure projects are under the financial and administrative control of the federal government. The former includes types of infrastructure projects: roadways and railways. ${ }^{17}$ One is the expansion and reconstruction of the Main Line - 1 (Railways), and its connectivity to the dry port of Kashgar, the terminal city of China, and makes for one of the two ambitious projects under the CPEC. The other is a collection of roadways projects connecting China to Gwadar and Karachi through several highways. The implementation authority for the highways and motorways is the National Highway Authority (NHA), a federal agency under the Ministry of Communications (MOC) and it implements road construction projects under the National Highway Authority Act of 1991 (NHAA) ${ }^{118}$ and its Code of 2005 (NHAC). ${ }^{119}$ The railways' projects are in

\footnotetext{
${ }^{116}$ Erica Downs, "China-Pakistan Economic Corridor Power Projects: Insights into Environmental and Debt Sustainability" (New York, NY: SIPA Centre on Global Energy Policy, October 2019), Government of Pakistan, http://cpec.gov.pk/project-details/; https://www.energypolicy.columbia.edu/research/report/china-pakistan-economiccorridor-power-projects-insights-environmental-and-debt-sustainability.'

${ }^{117}$ Khuram Iqbal, "Securing CPEC: Challenges, Responses and Outcomes," in Securing the Belt and Road Initiative (Springer, 2018), 197-214.

118 "National Highway Authority Act, 1991, Act XI of 1991, Enacted 1991, (Government of Pakistan)" (n.d.)

119 "National Highway Authority Code (Enforced by National Highway Authority of Pakistan, Established in 1999 and Amended in 2005) Available at:

Http://Nha.Gov.Pk/En/Document/Nha-Act/" (n.d.).
} 
A Comparative Analysis of the Environmental Policies in China and...

the implementation phase under the control of the Pakistan Railways through the Railways Act of 1890, the law for rail-track development's safety and security. ${ }^{120}$

The threat to climate due to the cutting of trees to build these infrastructures shall cause severe climate issues, as would be the impact on water resources plus waste accumulation and their collective impact on human habitats. However, the laws mentioned above for the infrastructure projects mainly regulate the safety, quality and performance and do not regulate environmental protection and ecological concerns. Although the provincial governments are responsible for establishing and implementing the National Forest Policy of 2015, ${ }^{121}$ Punjab Plantation and Maintenance of Trees Act of $1974{ }^{122}$ and Forest Policy Statement of 1999, ${ }^{123}$ the EPA's in the provinces were never invited for IEE and EIA. ${ }^{124}$

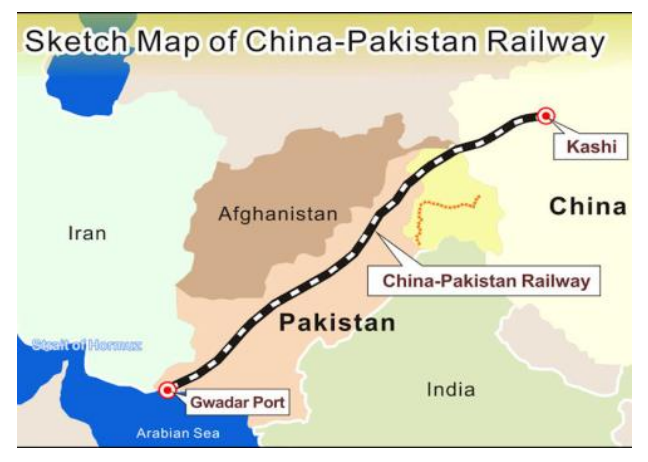

Figure 2: CPEC Railway Network Developing Phase (Doubling of entire track from Karachi to Peshawar, Speed of passenger trains to be raised from $65 / 110 \mathrm{~km} / \mathrm{h}$ to $160 \mathrm{~km} / \mathrm{h}$, Freight trains to operate at $120 \mathrm{~km} / \mathrm{h}$.) Rehabilitation \& Up-gradation of Karachi-Lahore Peshawar (ML-1), Railway Track (1,872 km).(Illustrated by the author)

Open Source: CPEC Projects, Rail-Sector Projects, China-Pakistan Economic Corridor (Official Website), Government of Pakistan, (http://cpec.gov.pk/).

\footnotetext{
120 "The Railways Act, 1890, Act IX OF 1890 (Re-Enforced by Government of Pakistan in 1949)" (n.d.).

${ }^{121}$ Bashir Ahmed Wani, "National Forest Policy Review."

${ }^{122}$ Sheraz Zaka, "Trees Plantation and Environmental Jurisprudence," Pakistan Today (blog), August 10, 2019, https://www.pakistantoday.com.pk/2019/10/08/trees-plantationand-environmental-jurisprudence/.

${ }^{123}$ Zaka; Zubair Qureshi, "Rs25,000 Fine for Chopping down a Tree in Pakistan's Punjab," Gulf News (blog), February 9, 2019, https://gulfnews.com/world/asia/pakistan/rs25000fine-for-chopping-down-a-tree-in-pakistans-punjab-1.66165737.

${ }^{124}$ Shamsa Kanwal et al., "Road and Transport Infrastructure Development and Community Support for Tourism: The Role of Perceived Benefits, and Community Satisfaction," Tourism Management 77 (April 1, 2020): 104014, https://doi.org/10.1016/j.tourman.2019.104014.
} 
Figure 3: CPEC Roadways Projects

Rehabilitation \& Up-gradation of Highways and Roadways

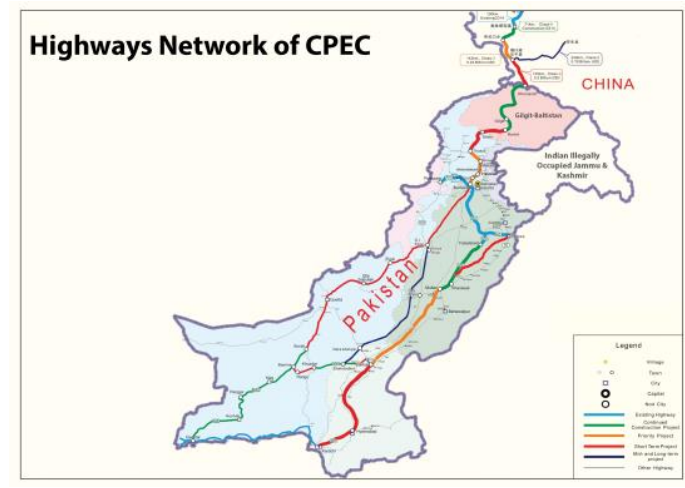

Open Source:

CPEC Projects, China-

PakistanEconomic Corridor

(Official Website), Government

of Pakistan, (http://cpec.gov.pk/)

Priority Projects (646 KMS)

Mid and Long-Term Project (110 KMS)

Short Term Project (210 KMS)

Table 5: Infrastruture Projects and Environmental Regulations

\begin{tabular}{|c|c|c|c|c|c|}
\hline \multirow[t]{2}{*}{$\begin{array}{l}\text { Sr. } \\
\text { No }\end{array}$} & \multirow[t]{2}{*}{ Projects } & \multicolumn{2}{|c|}{$\begin{array}{l}\text { Applicable Environmental } \\
\text { Laws }\end{array}$} & \multirow[t]{2}{*}{$\begin{array}{l}\text { General } \\
\text { Legislation }\end{array}$} & \multirow[t]{2}{*}{$\begin{array}{l}\text { Implementation } \\
\text { Authorities }\end{array}$} \\
\hline & & $\begin{array}{l}\text { National } \\
\text { Legislation }\end{array}$ & $\begin{array}{l}\text { Provincial } \\
\text { Legislation }\end{array}$ & & \\
\hline 1 & $\begin{array}{l}\text { Priority Projects } \\
\text { i.KKH Phase II } \\
\text { (Thakot -Havelian } \\
\text { Section) } 118 \mathrm{Kms} \\
\text { ii.Peshawar-Karachi- } \\
\text { Motorway (Multan- } \\
\text { Sukkur Section) } \\
392 \mathrm{Kms} \\
\text { ii. Thakot-Raikot- } \\
(136 \mathrm{Km})\end{array}$ & $\begin{array}{l}\text { Pakistan } \\
\text { Environmental } \\
\text { Protection Act, } \\
\text { Environmental } \\
\text { Impact } \\
\text { Assessment and } \\
\text { Initial, } \\
\text { National Forests } \\
\text { Policy (Revival } \\
\text { of Forests Act, } \\
\text { 1927) }\end{array}$ & $\begin{array}{l}\text { The Khyber } \\
\text { Pakhtunkhwa } \\
\text { Environmenta } \\
1 \text { Protection } \\
\text { Act } \\
\text { Gilgit- } \\
\text { Baltistan } \\
\text { Environmenta } \\
1 \text { Protection } \\
\text { Act }\end{array}$ & $\begin{array}{l}\text { National } \\
\text { Highway } \\
\text { Authority } \\
\text { Act, } 1991 \text {. } \\
\& \\
\text { National } \\
\text { Highway } \\
\text { Authority } \\
\text { Code, } \\
\text { 1995/2001 }\end{array}$ & $\begin{array}{l}\text { Ministry of } \\
\text { Communications } \\
\text { and National } \\
\text { Highway } \\
\text { Authority }\end{array}$ \\
\hline 2 & $\begin{array}{l}\text { Mid and Long- } \\
\text { Term Project } \\
\text { Khuzdar-Basima } \\
\text { Road N-30 }(110 \mathrm{~km})\end{array}$ & $\begin{array}{l}\& \\
\text { Environmental } \\
\text { Examination } \\
\text { Rules }\end{array}$ & $\begin{array}{l}\text { The } \\
\text { Balochistan } \\
\text { Environmenta } \\
\text { 1 Protection } \\
\text { Act }\end{array}$ & & \\
\hline
\end{tabular}


A Comparative Analysis of the Environmental Policies in China and...

\begin{tabular}{|c|c|c|c|c|}
\hline 3 & $\begin{array}{l}\text { Short Term Project } \\
\text { Upgradation of } \\
\text { D.I.Khan (Yarik) - } \\
\text { Zhob, N-50 Phase-I } \\
(210 \mathrm{~km})\end{array}$ & $\begin{array}{l}\text { The Punjab } \\
\text { Environmenta } \\
1 \text { Protection } \\
\text { Act and the } \\
\text { Balochistan } \\
\text { Environmenta } \\
\text { 1 Protection } \\
\text { Act }\end{array}$ & & \\
\hline$\overline{4}$ & $\begin{array}{l}\text { Rehabilitation \& } \\
\text { Up-gradation of } \\
\text { Karachi-Lahore } \\
\text { Peshawar (ML-1) } \\
\text { Railway Track } \\
(1,872 \mathrm{~km})\end{array}$ & $\begin{array}{l}\text { The } \\
\text { Provincial } \\
\text { Environmenta } \\
1 \text { Protection } \\
\text { Acts }\end{array}$ & $\begin{array}{l}\text { The } \\
\text { Railways } \\
\text { Act }\end{array}$ & $\begin{array}{l}\text { Pakistan } \\
\text { Railways }\end{array}$ \\
\hline
\end{tabular}

Source: Compiled and prepared by Authors, data retrieved from Official Database of the Ministry of Planning and Development, Government of Pakistan and China-Pakistan Economic Corridor Official Website, Government of Pakistan. ${ }^{125}$

\subsection{Unsustainable Gwadar: The City and Port}

Gwadar, the city, and port are one of the BRI gateways at the brink of CPEC, linking China through highways and railways to the African and European markets. Thus, more than $\$ 1$ billion worth of projects are in the implementation phase in Gwadar. ${ }^{126}$ Gwadar's seaport, airport, and smartcity plan are among major projects under CPEC other than small power generation, development zone, institute, and hospital development projects. ${ }^{127}$

\subsubsection{The Port}

The infrastructure phase of the Gwadar port commences with a publicprivate partnership governance model. ${ }^{128}$ BOI, MPDR, Gwadar Port Authority and the Federal Board of Revenue (FBR) under the Ministry of Finance and Cabinet Secretariat have driven the infrastructure

\footnotetext{
${ }^{125}$ Accessed through the Ministry of Planning and Development, Government of Pakistan. http://www.pc.gov.pk/ and China-Pakistan Economic Corridor Official Website,

Government of Pakistan, http://cpec.gov.pk/project-details/, last accessed 18 December 2020.

${ }^{126}$ Faisal Chaudhry, "Perspectives from Balochistan's Natural Gas Fields and the Port City of Gwadar," Globalization, Development and Security in Asia - The Political Economy of Energy, 2014, https://doi.org/10.1142/9789814566582_0035.

${ }^{127}$ Sajjad Ashraf, "Gwadar Will Be the Economic Funnel for the Region, Op-Ed, Page 24.," Gulf News (blog), May 24, 2017, https://gulfnews.com/opinion/op-eds/gwadarwill-be-the-economic-funnel-for-the-region-1.2032494.

${ }^{128}$ Iftikhar et al., "The Institutional and Urban Design of Gwadar City."
} 


\section{Jahanzeb Butt, Yen Chiang Chang \& Khadija Zulfiqar}

development agreement with the China Overseas Port Holding Company Ltd (China Port Holdings Company). China Port Holding Company is a State-owned enterprise in China, through which the agreement of Gwadar port development made the State of China, a party. ${ }^{129}$

Gwadar Port Authority is responsible for preparing a master plan and Gwadar port development programme under the Gwadar Port Authority Ordinance (Gwadar Ordinance). ${ }^{130}$ China Port Holding Company is constructing the breakwaters and building, dredging berthing areas and channels under the legal and institutional framework of Gwadar port. The EPA(s) initially sent notices to the Gwadar Port Authority and China Port Holdings Company for IEE and EIA conduct, and on technical grounds, the EPA(s) restricted for IEE and EIA. Later, the overall IEE of CPEC projects carried out by the International Union for Conservation of Nature was rejected by the PEPA without any apparent justification. ${ }^{131}$ PEPA stated that the report prepared by amateurs lacked specific details about the cutting of trees. ${ }^{132}$ Furthermore, the IEE included the impacts upon marine and terrestrial environments, and the PEPA does not consider them in the revision of IEE or EIA.

Protection of the marine environment is already problematic in Pakistan. It is threatened excessively due to the Gwadar port's development. Unlike several other states, there is not any specific legislation conjured upon marine environmental protection. The Balochistan Environmental Protection Act and the Sindh Environmental Protection Act that applies to the coastal zone cover port development in protecting the marine environment and such legislation neccessitaties

\footnotetext{
${ }^{129}$ Obortunity Info, "Chinese Company Grants $\$ 1.2$ bn for Gwadar Port's Development," Obortunity (blog), September 21, 2019, https://obortunity.org/2019/09/21/chinesecompany-grants-1-2bn-for-gwadar-ports-development/.

${ }^{130}$ Chapter 3, Power and Duties of Authority, Section - 10, Master-plan and Masterprogramme, "Gwadar Port Authority Ordinance, 2002," F. no. 2(1)/2002-pub (Ordinance No. LXXVII of 2002), Enforced by Pakistan Government, 2002, http://www.pljlawsite.com/Statuteview.asp?ID=2391\&offset=-1 $§$ (n.d.).

${ }^{131}$ Jamal Shahid, “"Environmental and Economic Sustainability' of CPEC Assured," The Dawn, 8, Islamabad, Pakistan (blog), June 2015, https://www.dawn.com/news/1186880/environmental-and-economic-sustainability-ofcpec-assured.

132 A. Khawaja, Saeed and Urooj, "Preliminary Environmental Impact Assessment, Study of China-Pakistan Economic Corridor, Northern Route Road Construction Activities in Khyber Pakhtunkhwa, Pakistan."
} 


\section{A Comparative Analysis of the Environmental Policies in China and...}

monitoring under strict guidelines for the environmental degradation caused by the ports and shipping. ${ }^{133}$ However, the latest marine environmental threats per the UNCLOS and London Convention's interpretation are not convincingly covered. The UNCLOS and London Convention signed and ratified by Pakistan lacks effective implementation; since it has neither the national legislation nor policy, i.e., PEPA, specified marine environmental protection. The fundamental governance problem in controlling marine pollution is overlapping jurisdiction between the three authorities, i.e., port authorities, EPAs (provincial and federal), and local authorities. Furthermore, there is no specific legislation in the field for marine pollution control and is under the general provisions of PEPA and provincial legislation.

\subsubsection{The City}

The smart city plan of Gwadar includes Pak-China Friendship Hospital, technical and vocational institute, east-bay expressway (highway), freezone and the airport. The Gwadar Development Authority mainly regulates the urban development of the city under the Gwadar Development Authority Act ${ }^{134}$ and the Gwadar building regulations have been recently updated for building control, safety and environmental monitoring. ${ }^{135}$ The Gwadar building regulations refers to implementing NEQS Regulations and Local Environmental Quality Standards to reduce air, water and land-based pollution. The regulations also administers the sanitation and solid waste management mechanism, accompanied by storm and rainwater drainage systems, and emphasises protecting existing woods. ${ }^{136}$ The regulations' approach seems effective in the development of

\footnotetext{
${ }^{133}$ Section 23 - Coastal Zone, "The Baluchistan Environment Protection Act," Act No. VIII of 2012 (No. PAB/Legis: V (9)/ Baluchistan Assembly, Came into force, 2013, Available at: https://elaw.org/system/files/balochistan_environment_protection_act_2012-1.pdf $\S$ (2013).

134 “Gwadar Development Authority Act (Act V of 2003), Enacted 2003 (Government of Pakistan)" (n.d.).

${ }^{135}$ Sohai Khan, "Builders Concerned over Gwadar Development Authority's New Town Planning Regulations," Samaa TV (blog), September 16, 2020 , https://www.samaa.tv/news/pakistan/2020/02/builders-concerned-over-gwadardevelopment-authoritys-new-town-planning-regulations/.

136 "Gwadar Building Regulations, 2020, Notification of the Gwadar Development Authority under Section. 24 of the Gwadar Development Authority Act, 2003, Enacted 2020 (Local Government of Gwadar, Baluchistan, Pakistan)" (n.d.).
} 


\section{Jahanzeb Butt, Yen Chiang Chang \& Khadija Zulfiqar}

an environmentally sustainable city; however, the implementation authorities lack specific capacity. ${ }^{137}$ The core problem identified in the Gwadar city development project is loose and has scattered coordination among environmental authorities and local government. In addition, Gwadar city residents are not co-opted in policy framework negotiation of Gwadar city or port. More precisely, the fisherman and fishing industry, who, to a great extent, are the local stakeholders in all these diverse developmental projects.

The Balochistan's EPA and Federal EPA both are empowered to conduct the IEE and EIA of the Gwadar coal-power generation project because it is implemented by the Federal authorities, i.e., Ministry of Planning, Power Board and Power Division of the Ministry of Energy. As it can be observed in Table 5, the Balochistan Environmental Protection Act empowers the Balochistan EPA to review the EIA before the commencement of any projects in its jurisdiction. Similarly, the PEPA authorises the Federal EPA to review the EIA of the projects prior to implementation through any Federal Agency. ${ }^{138}$

Table 6: Projects in Gwadar, the City and Port

\begin{tabular}{|c|c|c|c|c|c|}
\hline \multirow{2}{*}{$\begin{array}{l}\text { Sr } \\
\text { No }\end{array}$} & \multirow{2}{*}{ Project Title } & \multicolumn{2}{|c|}{ Applicable Environmental Laws } & \multirow{2}{*}{$\begin{array}{c}\text { Regulatory } \\
\text { Laws }\end{array}$} & \multirow{2}{*}{$\begin{array}{c}\text { Implementation } \\
\text { Authority }\end{array}$} \\
\hline & & $\begin{array}{l}\text { National } \\
\text { Legislation }\end{array}$ & $\begin{array}{l}\text { Provincial } \\
\text { Legislation }\end{array}$ & & \\
\hline 1 & $\begin{array}{l}\text { Port Projects } \\
\text { Construction } \\
\text { of } \\
\text { Breakwaters } \\
\text { Dredging of } \\
\text { berthing areas } \\
\text { \& channels }\end{array}$ & $\begin{array}{l}\text { Pakistan } \\
\text { Environmental } \\
\text { Protection Act, } \\
\text { Environmental } \\
\text { Impact } \\
\text { Assessment and } \\
\text { Initial, } \\
\text { National Forests }\end{array}$ & $\begin{array}{l}\text { Balochistan } \\
\text { Environmental } \\
\text { Protection Act } \\
\text { (Section 23- } \\
\text { Coastal Zone of } \\
\text { Balochistan } \\
\text { Environmental } \\
\text { Protection Act) }\end{array}$ & $\begin{array}{l}\text { Gwadar Port } \\
\text { Authority } \\
\text { Ordinance }\end{array}$ & $\begin{array}{l}\text { Ministry of } \\
\text { Maritime Affairs } \\
\text { and Gwadar Port } \\
\text { Authority }\end{array}$ \\
\hline
\end{tabular}

${ }^{137}$ Gwadar Building Regulations, 2020, Notification of the Gwadar Development Authority under Section. 24 of the Gwadar Development Authority Act, 2003, enacted 2020 (Local Government of Gwadar, Baluchistan, Pakistan).

${ }^{138}$ Section 12, Pakistan Environmental Protection Act. 
A Comparative Analysis of the Environmental Policies in China and...

\begin{tabular}{|c|c|c|c|c|c|}
\hline 2 & $\begin{array}{l}\text { Urban } \\
\text { Development } \\
\text { Plan } \\
\text { Gwadar } \\
\text { Smart Port } \\
\text { City Master } \\
\text { Plan }\end{array}$ & $\begin{array}{l}\text { Policy (Revival } \\
\text { of Forests Act, } \\
\text { 1927), National } \\
\text { Environmental } \\
\text { Quality } \\
\text { Standards } \\
\text { \& } \\
\text { Environmental }\end{array}$ & $\begin{array}{l}\text { Balochistan } \\
\text { Environmental } \\
\text { Protection Act }\end{array}$ & $\begin{array}{l}\text { Gwadar } \\
\text { Development } \\
\text { Authority Act } \\
\text { and } \\
\text { Gwadar } \\
\text { Building } \\
\text { Regulations }\end{array}$ & $\begin{array}{l}\text { Gwadar } \\
\text { Development } \\
\text { Authority and } \\
\text { Government of } \\
\text { Balochistan }\end{array}$ \\
\hline 3 & $\begin{array}{l}\text { Airport } \\
\text { Development } \\
\text { Plan } \\
\text { Gwadar } \\
\text { International } \\
\text { Airport }\end{array}$ & $\begin{array}{l}\text { Examination } \\
\text { Rules }\end{array}$ & & $\begin{array}{l}\text { Civil Aviation } \\
\text { Laws and } \\
\text { Gwadar } \\
\text { Building } \\
\text { Regulations }\end{array}$ & $\begin{array}{l}\text { Civil Aviation } \\
\text { Authority, } \\
\text { Aviation } \\
\text { Division under } \\
\text { Cabinet } \\
\text { Secretariat }\end{array}$ \\
\hline 4 & $\begin{array}{l}\text { Roadway } \\
\text { Project } \\
\text { Gwadar East- } \\
\text { Bay } \\
\text { Expressway }\end{array}$ & & & $\begin{array}{l}\text { Gwadar Port } \\
\text { Authority } \\
\text { Ordinance and } \\
\text { National } \\
\text { Highways } \\
\text { Authority Act }\end{array}$ & $\begin{array}{l}\text { Ministry of } \\
\text { Maritime Affairs } \\
\text { and Gwadar Port } \\
\text { Authority }\end{array}$ \\
\hline 5 & $\begin{array}{l}\text { Development } \\
\text { of Free Zone }\end{array}$ & & & $\begin{array}{l}\text { Regulatory } \\
\text { Laws of } \\
\text { Government } \\
\text { of Balochistan }\end{array}$ & $\begin{array}{l}\text { Gwadar } \\
\text { Development } \\
\text { Authority and } \\
\text { Government of } \\
\text { Balochistan }\end{array}$ \\
\hline 6 & $\begin{array}{l}\text { Pak-China } \\
\text { Friendship } \\
\text { Hospital }\end{array}$ & & & $\begin{array}{l}\text { Gwadar } \\
\text { Building } \\
\text { Regulations }\end{array}$ & $\begin{array}{l}\text { Gwadar } \\
\text { Development } \\
\text { Authority and } \\
\text { Government of } \\
\text { Balochistan }\end{array}$ \\
\hline 7 & $\begin{array}{l}\text { Pak-China } \\
\text { Technical and } \\
\text { Vocational } \\
\text { Institute at } \\
\text { Gwadar }\end{array}$ & & & $\begin{array}{l}\text { Gwadar } \\
\text { Building } \\
\text { Regulations }\end{array}$ & $\begin{array}{l}\text { Ministry of } \\
\text { Maritime Affairs } \\
\text { and Ministry of } \\
\text { Planning and } \\
\text { Development }\end{array}$ \\
\hline
\end{tabular}

Source: Compiled and prepared by authors, data retrieved from the official databases of the Ministry of Planning, China-Pakistan Economic Corridor, Gwadar Port Authority and, Gwadar Development Authority. ${ }^{139}$

\footnotetext{
${ }^{139}$ Ministry of Planning, Government of Pakistan. http://www.pc.gov.pk/, China-Pakistan Economic Corridor Official Website, Government of Pakistan, http://cpec.gov.pk/project-details/, Official Website of Gwadar Port Authority, http://www.gwadarport.gov.pk/, and, Official Website of Gwadar Development Authority, http://www.gda.gov.pk/.'
} 
M Jahanzeb Butt, Yen Chiang Chang \& Khadija Zulfiqar

\section{Analysis of Environmental Regulation of CPEC}

Besides the obstacles mentioned above, there are further overlapping jurisdiction issues, disintegration and fragmentation of resources, lack of uniformity and clarity between the authorities and departments handling CPEC projects. Jurisdiction of EPA(s) in the provinces overlaps with the jurisdiction of federal EPA, as the Ministry of Planning and Board of Investment implementing CPEC projects fall under the federal jurisdiction. ${ }^{140}$ Moreover, the EPA(s) have not conducted strict IEE and EIA of the CPEC projects; whereas the IEE and EIA mechanisms are outdated and unclear because the CPEC projects employ the latest machinery to develop modern infrastructure. Corporations implementing CPEC projects already informed the EPA(s) that they follow China's Environmental Regulations, which are quite inconsistent with Pakistan's ground conditions. The following figure can help us understand the multilayered complexities and a bureaucratic inertia underpinning the areas of formulation, implementation and evaluation/accountability.

Figure 4: Overlapping Jurisdiction and Dis-Integration: The Law and Institutions/Authorities
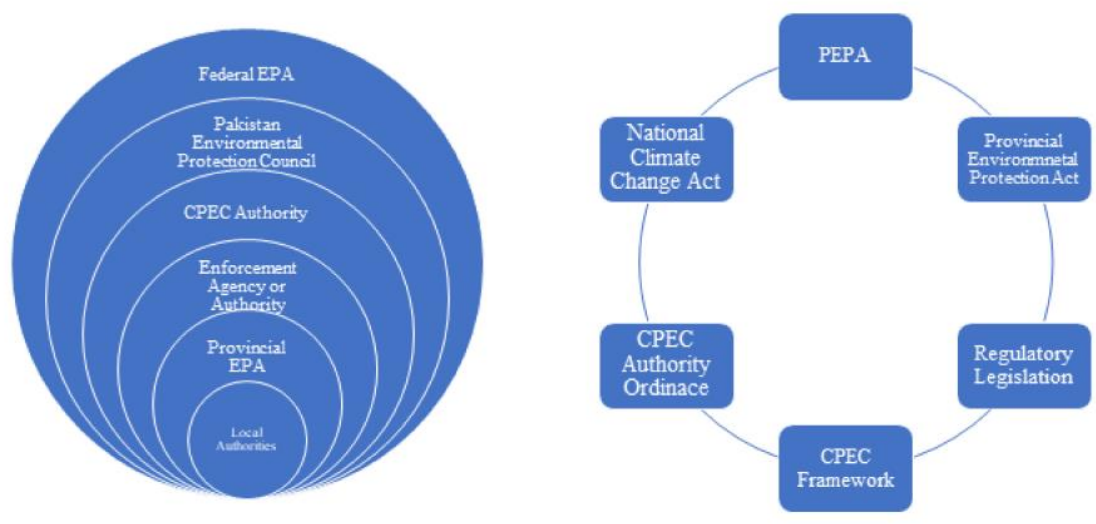

Experts of the International Union for Conservation of Nature, in their report, stated that the legislation regarding hazardous waste,

\footnotetext{
${ }^{140}$ See Figure - 1, prepared with the assistance of the report: "Environmental Protection and the Eighteenth Amendment."
} 


\section{A Comparative Analysis of the Environmental Policies in China and...}

emission control, forest management and shipping lacks uniformity and thus crucially disintegrates the power to control and enforce. Their report indicated that more ecological issues will arise due to seven on-going and near-completion infrastructure projects under CPEC surging 60 per cent of the daily toll in traffic through Pakistan, such as reconstruction of the most extensive railway line of Pakistan, along with two relatively small main lines. ${ }^{141}$ Moreover, the report highlighted that the coal-based power generation projects, as well as a rise in shipping from and through the development of the Gwadar port, and intensification of special economic zones will worsen the air quality in the country. ${ }^{142}$ These developments are significant in producing massive emissions, ${ }^{143}$ and these challenges to the environment require a policy mechanism integrating air, marine and terrestrial ecosystems.

Another report on CPEC and Gwadar by the International Growth Centre (IGC) explained that the projects in Gwadar (the city and the port) are not uniformly administered and is a classic example of hotchpotch governance. ${ }^{144}$ Consequently, Gwadar, a prime project under the CPEC, appears to pose an unsustainable future owing to the lack of coordination among provincial, local and federal authorities. Such inefficacies are not new in Pakistan; failure of urban governance is apparent as has been ostensible over flooding in Karachi. The tussle among authorities exists in almost all the urban centres impacting not only environmental regulation but also social and economic stability. In implementing environmental regulation, the dilemma is paucity in monitoring and evaluation mechanisms, not fulfilling the international commitments under the Aarhus Convention, UNCLOS, Stockholm and Rio Declarations. ${ }^{145}$

\footnotetext{
${ }^{141}$ Shamsa Kanwal et al., "Assessment of Residents' Perceptions and Support toward Development Projects: A Study of the China-Pakistan Economic Corridor," The Social Science Journal 0, no. 0 (February 5, 2020): 1-17, https://doi.org/10.1016/j.soscij.2019.08.001.

${ }^{142}$ Khalid Mehmood Alam, Xuemei Li and Saranjam Baig, "Impact of Transport Cost and Travel Time on Trade under China-Pakistan Economic Corridor (CPEC)," Journal of Advanced Transportation 2019 (February 25, 2019): 16, https://doi.org/10.1155/2019/7178507.

${ }^{143}$ Salik uddin Ahmed et al., "China Pakistan Economic Corridor and Pakistan's Energy Security: A Meta-Analytic Review," Energy Policy 127 (April 1, 2019): 147-54, https://doi.org/10.1016/j.enpol.2018.12.003.

${ }^{144}$ Iftikhar et al., "The Institutional and Urban Design of Gwadar City."

145 "Environmental Protection and the Eighteenth Amendment."
} 


\section{Jahanzeb Butt, Yen Chiang Chang \& Khadija Zulfiqar}

The CPEC Ordinance forming CPEC Authority will further complicate problems; being under the direct control of the federal government will circumvent the EPA(s), while implementing development projects. ${ }^{146}$ The CPEC Ordinance is ambiguous while establishing measures for regulatory authorities' for an inter-coordination mechanism for environmental protection. There are no specific regulations or instruments in place to regulate environmental issues. ${ }^{147}$ Therefore, it is proposed to establish a coordinated and interlinked mechanism for environmental protection to be supervised jointly by the Ministry of Climate Change, Provincial Environmental Administration, PEPCs, EPA(s) and other relevant authorities. The interlinked departments or ministries or divisions are imperative stakeholders in environmental policy, such as development authorities like Ministry of Planning, Planning and Development Division, Agricultural Authorities, Fisheries Authorities, Port and Shipping Authorities. PEPC, as it is empowered for policymaking, may play a pivotal role in national, provincial and local consultations with stakeholders. Such consultations may extend to the on-going and upcoming development projects, including the CPEC. There must be a re-assessment and re-examination of CPEC projects to be jointly carried by the EPA(s) and local or enforcement authority. Understandably, devolution of authority to implement environmental regimes to the provincial, local and administrative authorities is necessary to avoid environmental risks. ${ }^{148}$ The above considerations, if taken aboard, may provide effective means to strike a balance between environmental protection and economic development as shown in figure below, besides leading the country towards a cherished and sustainable progress while totally rooted in ecological imperatives.

\footnotetext{
${ }^{146}$ Mir Sher Baz Khetran and Muhammad Anjum Saeed, "The CPEC and China-Pakistan Relations: A Case Study on Balochistan," China Quarterly of International Strategic Studies 3, no. 03 (2017): 447-61.

${ }^{147}$ Huma, "Pakistan's Environmental Challenges."

148 "Environmental Protection and the Eighteenth Amendment."
} 
Figure 5: Proposed Framework of Coordination and Collaboration

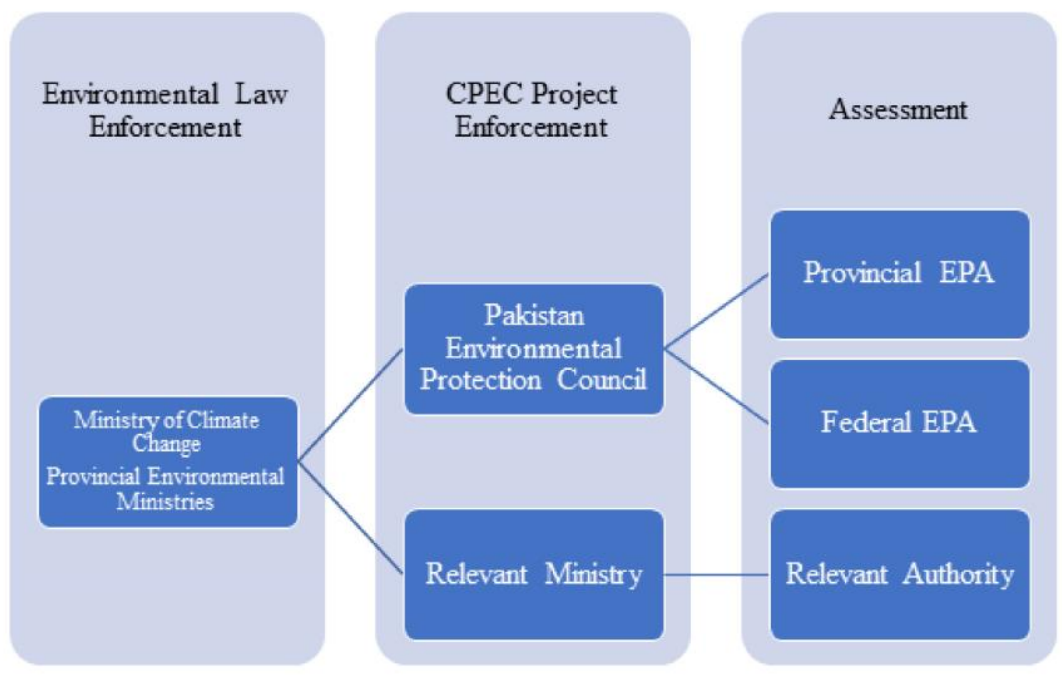

\section{Conclusion}

Although the development of Pakistan through CPEC investment is new and essential, environmental degradation is as old as initial industrialisation and may pose formidable challenges in the years to come for the human and animal habitats across the Indus regions. Unfortunately, despite having a new framework of (CPEC) investment for infrastructure, energy, port and industrial development, environmental protection is not incorporated as a priority, leaving it ambiguously to the various disparate organs of the state often lacking in focus and coordination. So far, ecological protection is being implemented through traditional or conventional approach, and technicalities of governance, policy and institutional frameworks stay overlooked. In addition, there is a lack of capacity building, technical expertise, and proficiency in implementing environmental legal frameworks. Hence, there is a dire need to revisit the existing environmental legislation, institutional framework, governance and policy mechanism under professional, technical and proficient environmental experts. Such expertise should not be limited to legal knowledge but should extend to technical expertise under the watchful eyes of a diverse arena of stake-holders and citizenry. 